\title{
ACCUMULATION DISTRIBUTION IN TERRE ADÉLIE, ANTARCTICA: EFFECT OF METEOROLOGICAL PARAMETERS
}

\author{
By P. PETTRE, \\ (Centre National de Recherche Meteorologiques, 31057 Toulouse Cedex, France) \\ J.F. Pinglot, M. POURChet, and L. REYNAUD \\ (Laboratoire de Glaciologie et Géophysique de l'Environnement, 38402 Saint-Martin-d'Hères Cedex, France)
}

\begin{abstract}
Along the $1040 \mathrm{~km}$ extending from Cape Prud'homme (lat. $66^{\circ} 41^{\prime}$ S., long. $139^{\circ} 55^{\prime}$ E.), near Dumont d'Urville station, to Dome C (lat. $74^{\circ} 39^{\prime}$ S., long. $124^{\circ} 10^{\prime}$ E.), the variations in annual accumulation can be analysed by a division of the entire data set into three sub-sets depending on the types of measurements and the character of the spatial distribution. Along the first $33 \mathrm{~km}$, from the coast to stake E40, annual measurements show considerable inter-annual variability, $52 \%$ of which can be explained by the spatio-temporal homogeneity of the balance distribution. However, we obtain a better result $(64 \%)$ for the fluctuation homogeneity standardized using the standard deviation. This means that there is a strong space-time distribution structure, characterized by an equal variation of the balance around the mean value specific to each location. This is so in spite of the existence of considerable surface roughness (sastrugi), the influence of which should be reduced by averaging values around each stake. From stake E40 to stake R60, a distance of $170 \mathrm{~km}$, the almost periodic oscillations in the accumulation with a wavelength close to $40 \mathrm{~km}$ can be explained by the formation of a gravityinertia wave, disturbing the geostrophic equilibrium, occurring at the break in slope $200 \mathrm{~km}$ from the coast. The very low values of accumulation for stakes D55 and D58S show that the oscillations were almost stationary during the study period (about 25 years). Finally, along the $840 \mathrm{~km}$ from stake R60 to Dome $C$ we can observe a decrease in accumulation resulting from the decrease in mean temperature.
\end{abstract}

RÉsumÉ. La distribution d'accumulation en Terre Adélie, Antarctique: effet de paramètres météorologiques. Sur les $1040 \mathrm{~km}$ de Cap Prud'homme $\left(66^{\circ} 41^{\prime} \mathrm{S}\right.$., $139^{\circ} 55^{\prime}$ E.) situé à proximité immédiate de la station Dumont d'Urville à Dôme C $\left(74^{\circ} 39^{\prime} \mathrm{S}\right.$., $124^{\circ} 10^{\prime} \mathrm{E}$.) les variations de l'accumulation annuelle peuvent être analysées en partitionant l'ensemble des données en trois sous-ensembles en fonction des types de mesures et des caractères de distribution spatiale. Sur les 33 premiers $\mathrm{km}$, de la cóte à la balise E40, les mesures recueillies chaque année montrent une grande variabilité interannuelle dont une partie $(52 \%)$ peuvent être expliquée par l'homogénéité de distribution du bilan. Cependant on obtient un meilleur score (64\%) pour l'homogénéité de la fluctuation normée par l'écart type. C'est-à-dire qu'il existe une forte structure de répartition spatio-temporelle caractérisée par une variation identique du bilan autour de d'une important rugosité de surface (sastrugi), dont il la moyenne propre à chaque site. Ceci malgré l'existence

\section{INTRODUCTION}

Snow accumulation at a fixed point is the result of the re-distribution and modification of fallen precipitation by various processes: wind and relief effects, thinning of the layers due to ice flow, melting, sublimation, etc.

For the Antarctic ice sheet, only the re-distribution induced by wind and relief plays an important part at the conviendrait de réduire l'influence en moyennant les mesures autour de chaque balise. De E40 à R60, sur $170 \mathrm{~km}$, les oscillations quasi périodiques de l'accumulation avec une longueur d'onde voisine de $40 \mathrm{~km}$ peuvent s'expliquer par la formation d'une onde de gravité inertie perturbant l'équilibre géotropique prenant son origine à la rupture de pente vers $200 \mathrm{~km}$ de la côte. Les très faibles valeurs de l'accumulation pour les stations D55 et D58S indiquent que ces oscillations sont sensiblement stationnaires durant la période étudiée ( 25 ans environ). Enfin sur les $840 \mathrm{~km}$ de R60 à Dôme $C$ on peut observer la décroissance de l'accumulation entraînée par la diminution des températures moyennes.

ZUSAMMENFAsSUng. Verteilung des Schneeauftrages in Terre Adélie, Antarktika: Einfluss der meteorologischen Parameter. Entlang des $1040 \mathrm{~km}$ langen Profils von Cape Prud'homme $\left(66^{\circ} 41^{\prime}\right.$ südl. Br., $139^{\circ} 55^{\prime}$ östl. L.) nahe der Station Dumont d'Urville zum Dome C $\left(74^{\circ} 39^{\prime}\right.$ südl. Br., $124^{\circ} 10^{\prime}$ östl. L.) können die Schwankungen der jährlichen Akkumulation durch Unterteilung des gesamten Datensatzes in drei Teilsätze in Abhängigkeit von den Messverfahren und vom Charakter der räumlichen Verteilung analysiert werden. Längs der ersten $33 \mathrm{~km}$, von der Küste bis Pegel E40, zeigen die jährlichen Messungen eine beträchtliche Schwankungsbreite während des Jahres; $52 \%$ davon können mit der raum-zeitlichen Homogenität der Bilanzverteilung erklärt werden. Ein besseres Ergebnis (64\%) für die standardisierte Schwankungshomogenităt lässt sich jedoch gewinnen, wenn man die Standardabweichungen heranzieht. Das bedeutet, dass eine starke raum-zeitliche Verteilungsstruktur vorliegt, die sich durch eine gleichmässige Schwankung der Bilanz um den für jede Stelle spezifischen Mittelwert charakterisieren lässt. Dies gilt trotz einer erheblichen Oberflächenrauhigkeit (Sastrugi), deren Einfluss sich durch Mittelung der Werte im Umfeld jedes Pegels verringern sollte. Von Pegel E40 bis Pegel R60, auf eine Strecke von $170 \mathrm{~km}$, können die nahezu periodischen Oszillationen in der Akkumulation mit einer Wellenlänge bei $40 \mathrm{~km}$ durch die Bildung von Schwerkraft-Trägheits-Wellen erklärt werden, die das geostrophische Gleichgewicht stören, das am Gefällsbruch $200 \mathrm{~km}$ von der Küste auftritt. Die sehr niedrigen Akkumulationswerte für die Pegel D55 und D58S zeigen, dass die Oszillationen während der Untersuchungsperiode ( 25 Jahre) nahezu stationär waren. Längs der $850 \mathrm{~km}$ von Pegel R60 bis Dome C schliesslich ist eine Abnahme der Akkumulation infolge der Abnahme der Mitteltemperatur zu beobachten.

surface. This phenomenon can sometimes cause major accumulation differences for stations only a few kilometers apart. When a fixed-point measurement is not the aim, this effect can be minimized by taking a representative sample with greater spatial coverage. The range of ten used for such smoothing is in the order of $50 \mathrm{~km}$ (Young and others, 1982). For the Terre Adélie area, where many measurements are available, each one covering the last two or three 
decades, we have established a simple mathematical relationship which gives a good estimate of accumulation and which accounts for the spatial oscillations observed, starting at the break-in-slope with the Antarctic plateau. These oscillations could be the result of a meteorological phenomenon which is discussed in detail.

Time-scales for meteorology and glaciology are very much different: a few hours in the first case, several months in the latter. These two disciplines are difficult to compare and the assumptions made are therefore often difficult to check. However, we have confidence in our findings for Antarctica, because of its geophysical uniformity (proximity to the South Pole, permanent snow cover over the entire surface, less disturbed relief, etc.)

\section{MEASUREMENTS AND SAMPLING TRAVERSES}

Between January 1971 and January 1983, during several measurement and sampling traverses, the accumulation along the Dumont d'Urville-Dome C axis (Fig. 1) was determined at many stations in a stake network and also by ice-core analysis based on the radioactive reference levels due to atmospheric nuclear tests.

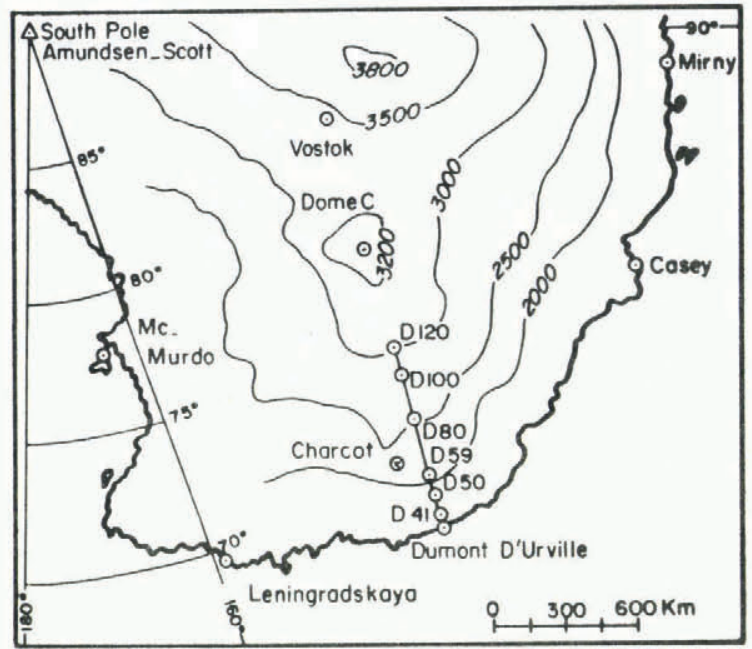

Fig. 1. Map of Antarctica showing the Terre Adélie area and the sampling traverse.

Between the coast and stake E40, located $33 \mathrm{~km}$ inland, 40 stakes were planted in January 1971. These stakes were measured every austral summer.

Beyond stake E40, the stake spacing is about $10 \mathrm{~km}$. Moreover, for 31 stations between the coast and stake R80 (located $430 \mathrm{~km}$ inland), very accurate snow sampling has been conducted (generally more than six samples per year) for the measurement of total beta-radioactivity.

These measurements give the depths corresponding to the radioactive reference levels of January 1955 (Picciotto and Wilgain, 1963) and January 1965 (Crozaz, 1969) which have been widely used for dating snow layers in Antarctica (Picciotto and others, 1964; Lambert and others, 1977; Pourchet and others, 1983).

Between R80 and Dome C, accumulation is only known at two stations (D100 and D120). For Dome C, it corresponds to the mean value of 22 ice cores sampled over a few kilometers. Some of these results have already been published (Lorius and others, 1970; Lambert and others, 1977; Petit and others, 1982; Pourchet and others, 1983) and complementary profiles available are given here (Fig. 2a and b).

In parallel with accumulation measurements, the $10 \mathrm{~m}$ depth temperature of the snow was determined for about 30 stations. The measurements were made in ice-core holes during several traverses with thermistors pre-calibred over the relevant range. Their accuracy is about $\pm 0.5^{\circ} \mathrm{C}$.

Station elevations were initially measured by a barometric survey using a $10 \mathrm{~km}$ spacing (1971-72 traverse).
During this survey, pressures between two successive stations were measured simultaneously. During two other traverses (austral summers of $1980-81$ and 1982-83) a Doppler-effect survey, between the coast and station R80, allowed us to determine accurately the elevation of 15 stations. For station $R 80$, the difference between the two methods was $92 \mathrm{~m}$.

These 15 stations also allowed us to calibrate a precise barometric survey (every $1 \mathrm{~km}$ ) made during the 1982-83 traverse. Distance measurements were done for all the Doppler-effect located stations (accuracy within a few meters) with vehicle odometers.

The maximum spacing between two successive Dopplereffect located points was $50 \mathrm{~km}$ and the distance accuracy of intermediate points (measured by vehicle odometers) was about $1 \mathrm{~km}$.

Between the coast and station E40, snow accumulation has been converted to water equivalent using a mean densification curve (Fig. 3). It results from the compilation of many density profiles available for this area. For the relevant depths, a good estimate of this density is given by the relationship:

$$
D=-3.73 \times 10^{-4} z^{2}+0.01427 z+0.430
$$

where $D\left(\mathrm{Mg} \mathrm{m}^{-3}\right)$ represents mean density between the surface and depth $z$ (expressed in meters).

Assuming that the bottom of each stake is firmly fixed relative to the snow layer in which it lies, the mean annual accumulation $(A)$ is given by the relationship:

$$
A=\frac{z_{2} D_{2}-z_{1} D_{1}}{t_{2}-t_{1}}
$$

where $z_{2}$ and $z_{1}$ represent snow cover at the stake at times $t_{2}$ and $t_{1}$, and $D_{2}$ and $D_{1}$ are the mean densities between the surface and depths $z_{2}$ and $z_{1}$.

The mean annual accumulation between 1971 and 1983 was determined by this method for each stake (Table I).

Beyond station E40, the snow depth-water equivalent conversion was done using the densification curve of the nearest measured station, which was never further away than $30 \mathrm{~km}$.

\section{INTERPRETATION OF THE ACCUMULATION MEASUREMENTS}

Between the coast and stake E40

Along these first $33 \mathrm{~km}$, a set of annual accumulation values measured at 40 stakes is available for the period 1971 to 1983 (Table I). The mean values of the annual balances are plotted in Figure 4 as a function of the distance to the coast, together with the mean surface slope between successive stakes. Note that each irregularity in the topography shows a corresponding major change on the balance curve, mainly involving a deficit up-stream of the break in slope and an excess just down-stream. But the main characteristic of this set of balance values is the great inter-annual variability, in the order of $70 \%$ of the mean. This value is slightly lower than that deduced from accumulation variations between the two decades 1955-65 and 1965-75 for a large part of Antarctica (Pourchet and others, 1983).

The question that immediately arises when confronted by a set of data affected by such high variability is whether these variations are randomly distributed or whether they in fact express a spatio-temporal distribution mode. This is important in a set of measurements in order to distinguish what is characteristic of the particular location from what may be a feature of the year; for example, to take into account several sets of measurements made at several stations in Antarctica when making a comparison.

For this purpose, we tested two mass-balance distribution models using the values in Table I, only retaining complete annual series, i.e. 16 stakes over a 10 year period (D05, 05 bis, 07, 08, 09, 10, 11, 15, 19, 21, $22,23,27,36$, and 37 ).

The first simple model tested was the one proposed by Lliboutry (1974), which assumes an equal inter-annual 
a

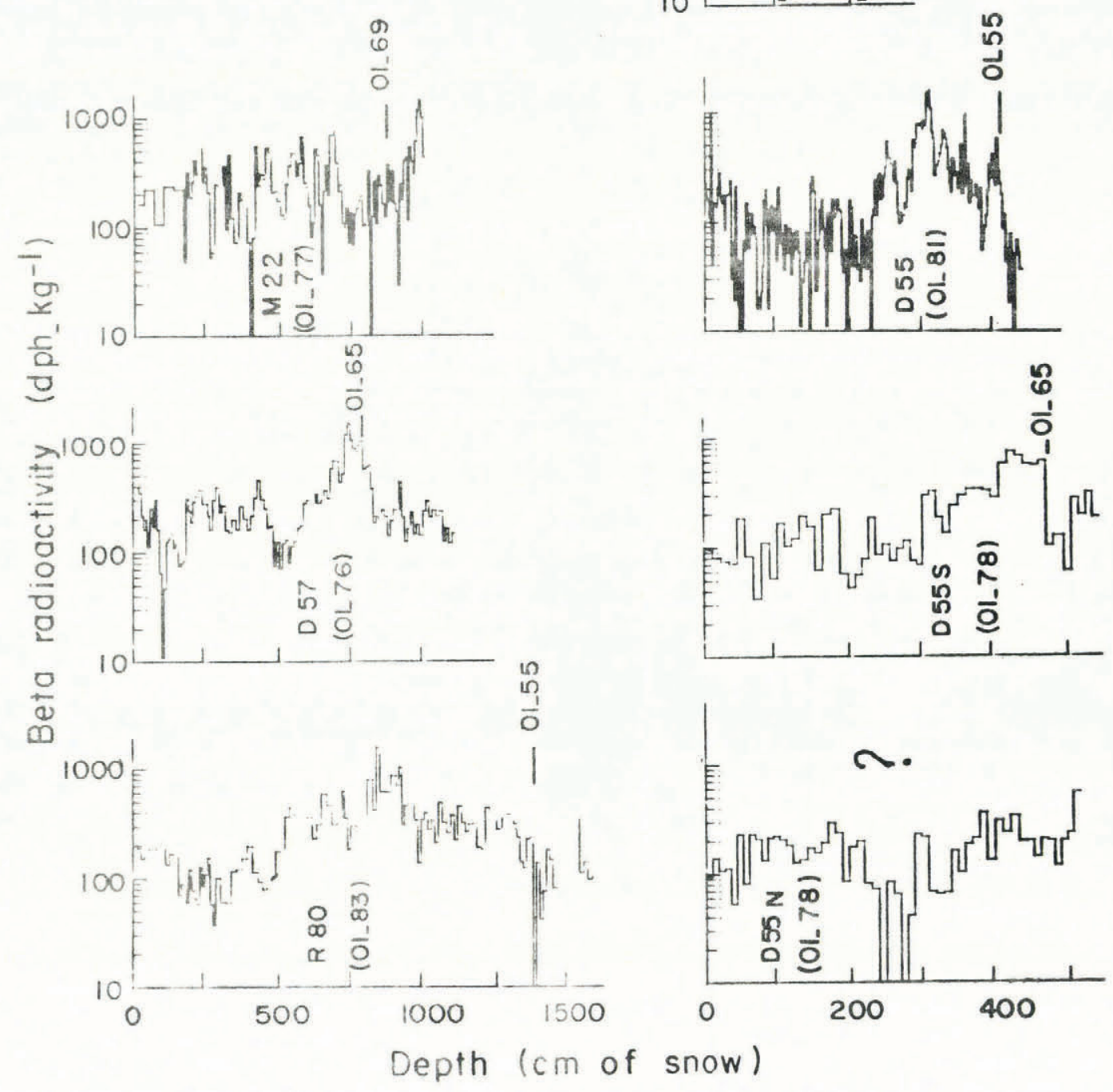

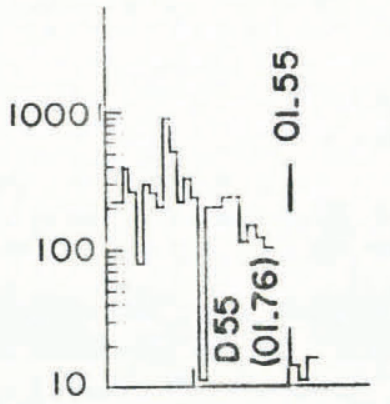

variation around the mean value of the balance for the stations. If $b_{j t}$ is the balance measured at site $j$ for year $t$, it may be broken down into three terms:

$$
b_{j t}=\alpha_{j}+\beta_{t}+\epsilon_{j t}
$$

where $\alpha_{j}$ is the mean value characteristic of site $j$, independent of time with

$$
\boldsymbol{\alpha}_{j}=\sum_{t=1}^{T} b_{j t} .
$$

$\beta_{t}$ is the centred variation of the balance

$$
\left[\begin{array}{l}
T \\
\sum \\
1
\end{array} B_{t}=0\right),
$$

which does not depend upon the site and is identical for all the stakes, and $\epsilon_{j t}$ is a centred random residual, the standard deviation of which expresses the adequacy of the model with respect to reality. In practice, in order to test this model on real values by variance analysis, a table of centred values $b_{j t}-\alpha_{j}$, which are the terms of the expression $\beta_{t}+\epsilon{ }_{j t}$, was deduced from the table of $b_{j t}(J$ stakes and $T$ years), for each of $T$ years; the value of $B_{t}$ is given by

$$
\frac{1}{J} \underset{J}{\Sigma}\left(b_{j t}-\alpha_{j}\right)
$$

and the real values for each stake are different by $\epsilon_{j t}$. The overall variance of the sample

$$
S^{2}{ }_{t}=\sum_{t=1}^{T} \sum_{J=1}^{J}\left(b_{j t}-\alpha_{j}\right)^{2}
$$

is the sum of the variance explained by an identical $\beta_{t}$ each year at the $J$ sites: 


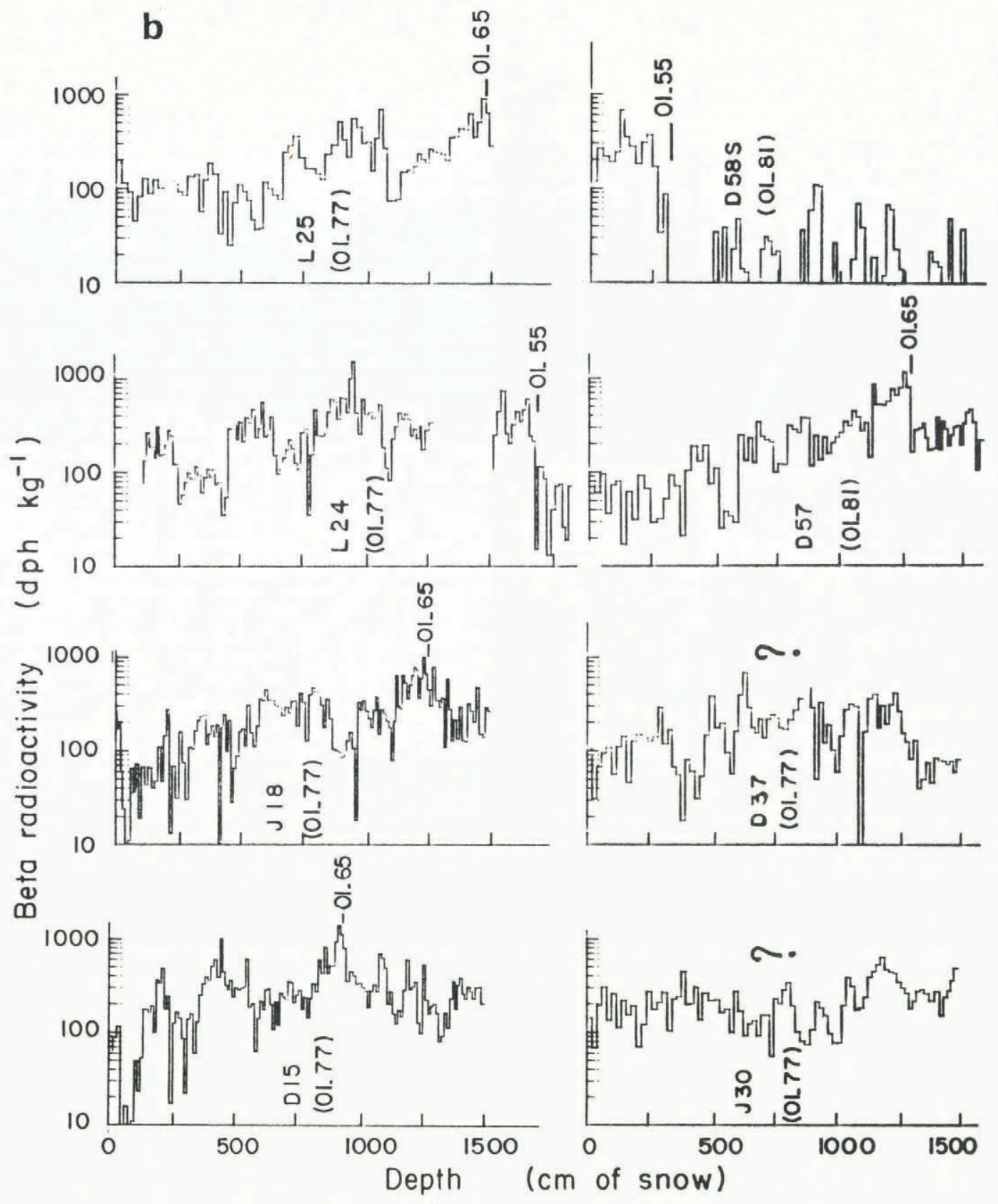

Fig. $2 a$ and $b . \quad B$ radioactivity (in $d p h$ per $\mathrm{kg}$ of ice) versus depth (in $\mathrm{cm}$ of snow) along the Dumont d'Urville-R80 axis. For each station, the B levels used and the date of sampling () are indicated.

$$
S_{\mathrm{e}}^{2}=\underset{1}{J \sum_{1}^{T} \beta_{t}^{2}}
$$

and the residual variance

$$
\begin{aligned}
& S_{\mathrm{r}}^{2}=\sum_{t=1}^{T} \sum_{J=1}^{J} \epsilon^{2}{ }_{j t} \\
& S^{2}{ }_{t}=S^{2}{ }_{\mathrm{e}}+S_{\mathrm{r}}^{2} .
\end{aligned}
$$

The degree of explanation $\tau=S^{2}{ }_{\mathrm{e}} / S^{2}$ is 0.52 , indicating that the linear model of balance variation takes into account $52 \%$ of the total variance of the sample.

The remaining $48 \%$ unexplained by this model is expressed by a residual standard deviation of $19 \mathrm{~cm}$ of water equivalent, i.e. about $40 \mathrm{~cm}$ of snow. Note that this corresponds to the mean height of the sastrugi observed in the area. This shows that it would be worthwhile to add a network of bamboos around each stake in order to obtain a mean value of the accumulation over a few square meters which would be more representative of the site than the single-point value.

In fact, the incomplete values determined at four bamboo networks available for one axis and the year 1972 alone (Table II), although insufficient to lead to significant numerical results, confirm the importance which should be attached to micro-relief.

Note also that these observations are similar to those already formulated for Dome C station (lat. $74^{\circ} 39^{\prime} \mathrm{S}$., long. $124^{\circ} 10^{\prime} \mathrm{E}$.) where the surface micro-relief is responsible, at a fixed-point sample, for a background value of the same order of magnitude as the annual accumulation: $\sigma=2.6 \mathrm{~g} \mathrm{~cm}^{-2} \mathrm{year}^{-1}$ for an accumulation of $3.6 \mathrm{~g} \mathrm{~cm}^{-2}$ year $^{-1}$ (Petit and others, 1982).

However, we find that the linear model gives only a rough approximation, since it is based on identical standard deviations along the profile, while the table of measurements indicates that they are highly variable. A second 


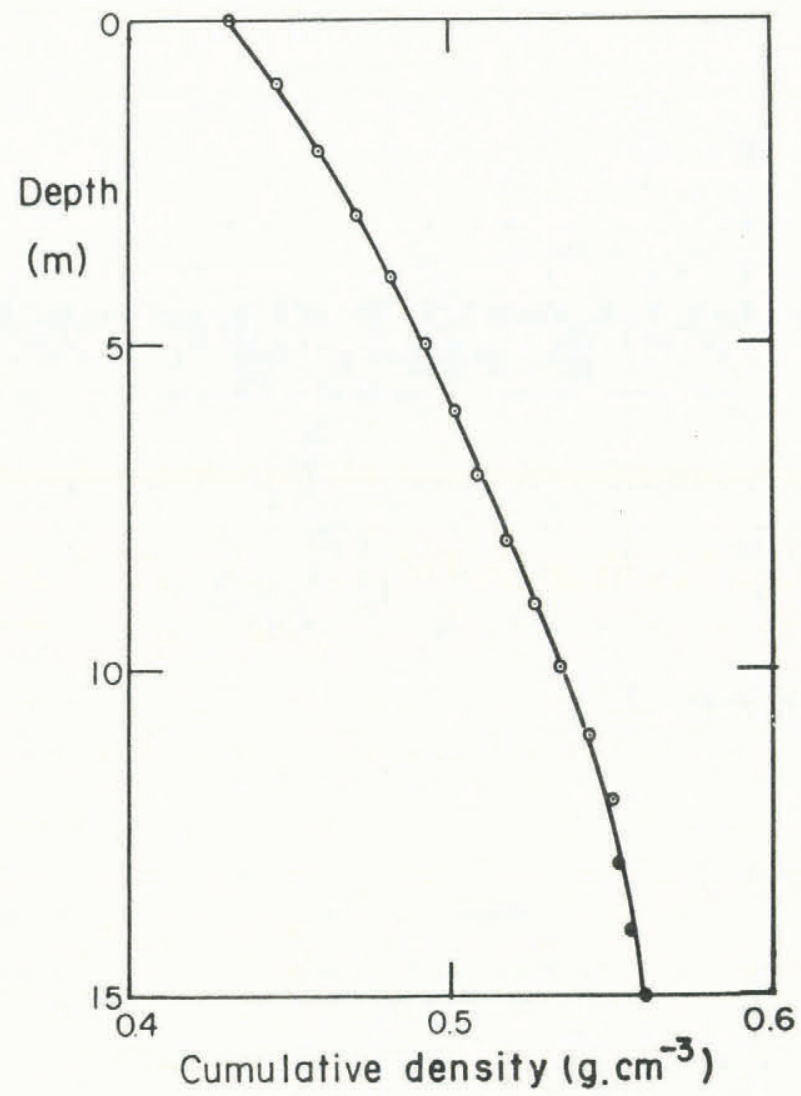

Fig. 3. Mean cumulative density curve between the coast and station E40. The cumulative density for the depth $z$ is the density between the surface and depth $z$. variance analysis can be conducted by comparing the variations of $B_{t}$ for a site reduced by the standard deviation, in order to analyse the relative variations.

This is the basis of principal component analysis, which compares reduced centred fluctuations. The results are given in Figure 5 which shows a common factor responsible for $64 \%$ of the variance and a second factor accounting for $10 \%$ of the variance, with $26 \%$ distributed on the other axes.

Axis 1 is interpreted as the consequence of the variation of homogeneity of the reduced centred balance, while axis 2 shows another trend differentiating the values in an apparently geographic manner, from the coast to the interior; this is somewhat unclear and opposite to other balance distributions such as those found in alpine-type mountain ranges (Reynaud and others, 1984). Finally, no known structure is apparent for the $26 \%$ of the variance explained on the other axes.

This is, however, not surprising taking into account the conditions of snow redistribution on the surface by wind which forms sastrugi. Under these conditions, it can be said that the spatio-temporal distribution homogeneity is certainly even more marked than found, and that far better results could be obtained if we were able to eliminate the background noise induced by the sastrugi. Using both radioactivity measurements and stake values, we also computed the mean value of accumulation for all the stations in this area and for the widest time period available (Table III). In each case, we mention the methods used as well as the relevant time period and the number of years represented. In some cases, our observations are discontinuous and as a result the number of years represented may be less than the time period of observation. For each accumulation value, we calculated an uncertainty $\sigma=s /(n-1)^{\frac{1}{2}}$ where $s$ is the standard deviation of the annual accumulation at each stake, during the period 1971-83, and $n$ is the number of years of observation.

This degree of uncertainty is much greater than the measurement errors. As previously mentioned, it mainly

TABLE I. MEAN ANNUAL ACCUMULATION BETWEEN 1971 AND 1983 FOR STAKES LOCATED BEYGND STATION E40

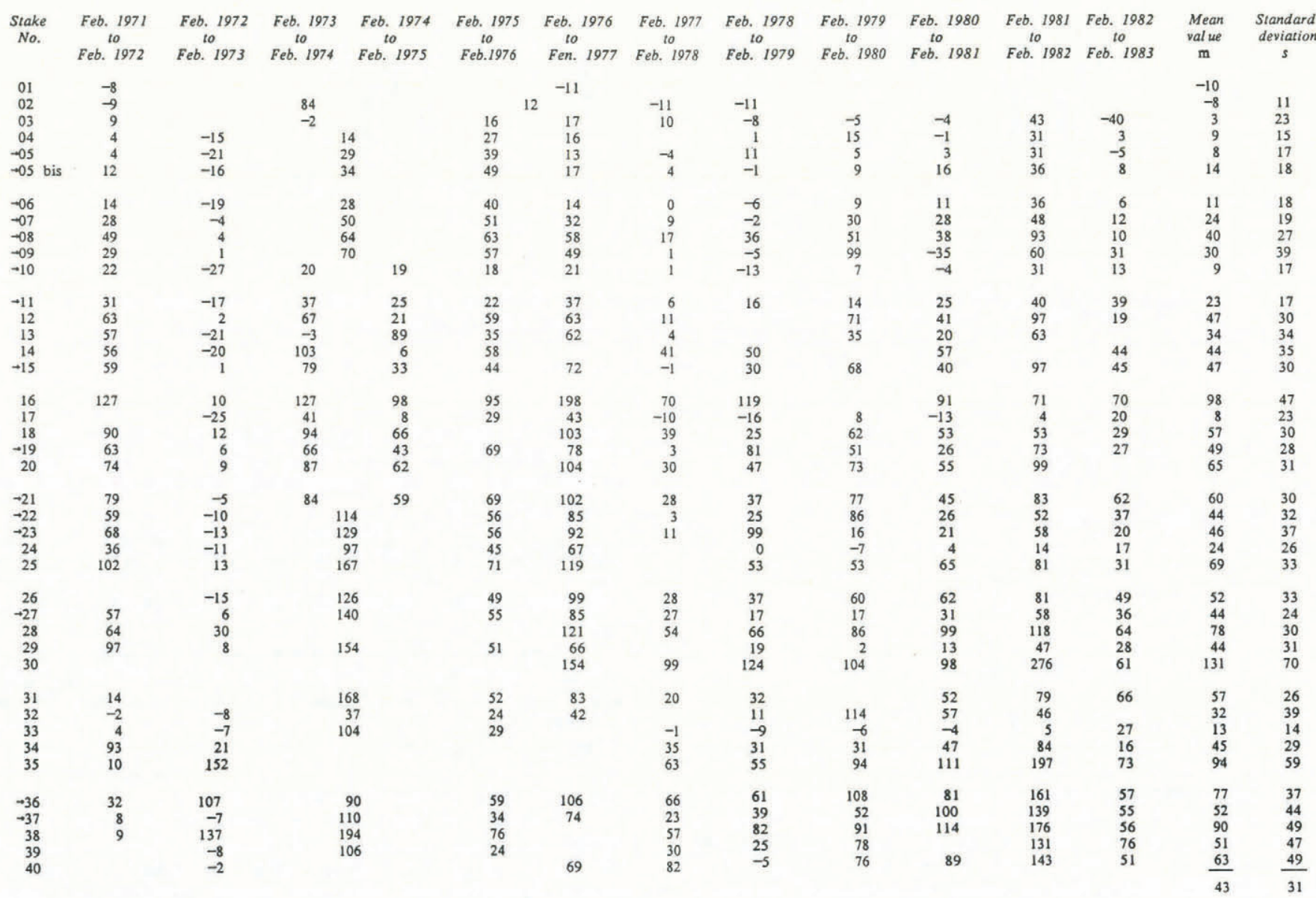




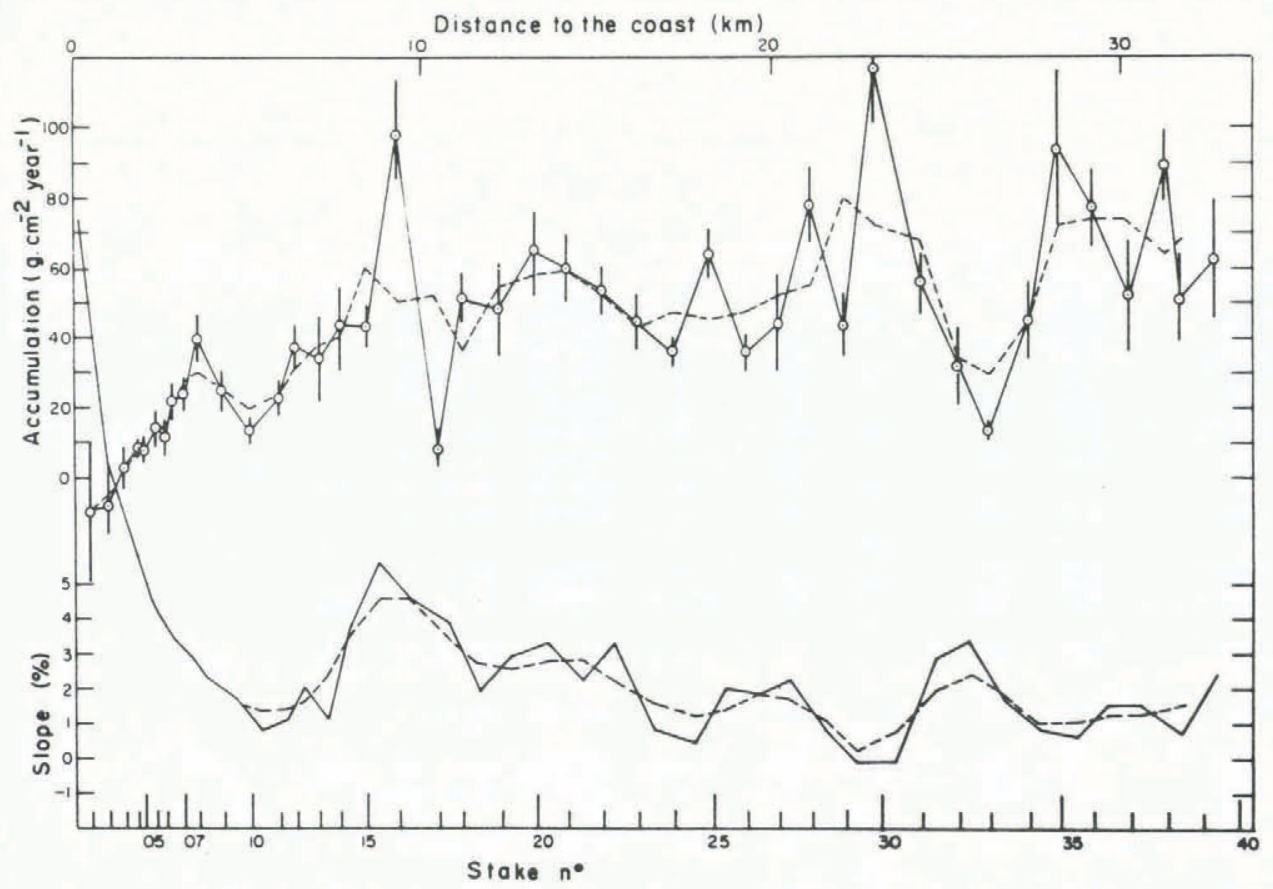

Fig. 4. Upper curves: mean values of the annual balance between the coast and stake E40 deduced from stake measurements for the period 1971-83. The 10 precision is plotted. Lower curves: slope change from one stake to the next. (---) three points running mean.

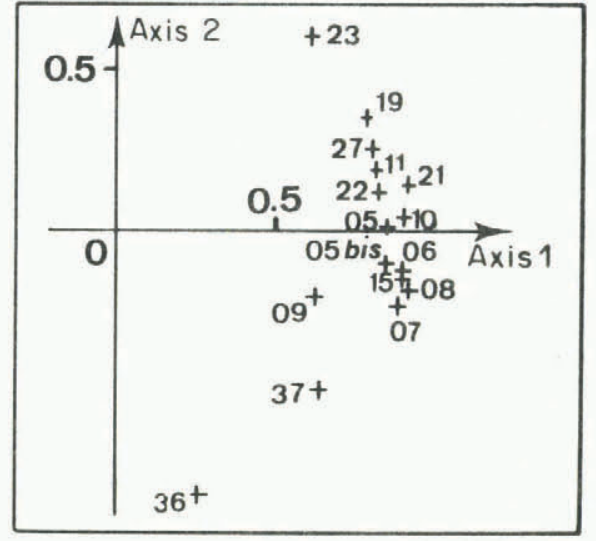

Fig. 5. Principal component analysis of reduced centred fluctuations of annual accumulation. For 10 years and 16 stakes (located between the coast and stake 37).

TABLE II. ACCUMULATION MEASUREMENTS AT THE BAMBOO NETWORKS FOR THE YEAR 1972

$\begin{array}{ccccc}\text { Stake No. } & D 9 & D 50 & D 59 & \text { D80 } \\ 1 & & 2.7 & 32.5 & 46 \\ 2 & -4 & 9 & & 15 \\ 3 & 14 & 27.5 & 41.3 & 30.6 \\ 4 & 42 & 35 & & 26.4 \\ 5 & & 30 & & 6.2 \\ 6 & 27 & 33 & 29.7 & 34.5 \\ 7 & -17 & 11 & 35.3 & 53 \\ 8 & 11.5 & 41 & & 36.2 \\ 9 & 43 & 39.5 & 42 & 33 \\ \bar{m} & 16.6 & 25.4 & 36.2 & 31.2 \\ \sigma & 55 & 40 & 11 & 40\end{array}$

reflects the temporal variation of accumulation and allows us to compare stations measured at different times.

Between the coast and stake D15 (Fig. 4), we noted a well-marked altitude effect. After D15, this effect becomes secondary relative to major deviations observed from one stake to another. These deviations cannot be directly attributed to variations in relief; between L25 and E40, accumulation increases in the "hollows" and decreases on the "hills"; however, this effect is reversed between stakes D15 and $\mathrm{L} 25$.

For this time period, ranging from 1971 to 1982 , we computed the annual accumulation in the area from D10 to D21 (Table IV). Comparing these values with mean annual temperatures at Dumont d'Urville (Fig. 6), we can deduce that the local mean annual temperature does not govern this variation in accumulation directly.

From the total set of observations, we conclude that between the coast and stake E40, the spatial variations in accumulation are considerable and cannot readily be

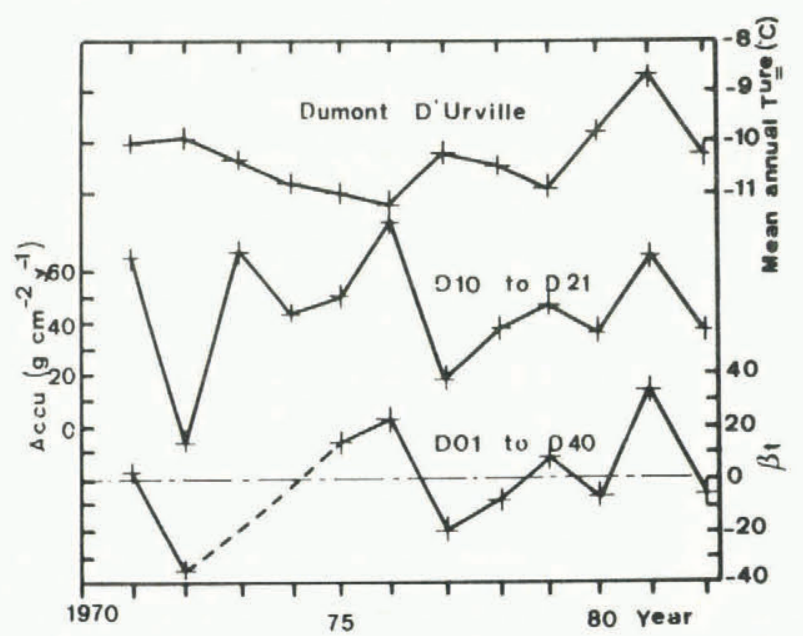

Fig. 6. Mean annual temperature at Dumont d'Urville (upper curve) compared with the mean annual accumulation between: D10 to D21 (middle curve); D01 to D40 (lower curve). 
TABLE III. TOPOGRAPHIC MEASUREMENTS AND ACCUMULATION RATE DETERMINED BETWEEN STAKE J01 AND STAKE E40

$\begin{array}{cccccc}\text { Station } & \text { Distance Altitude Slope } & \begin{array}{l}\text { Number } \\ \text { of years }\end{array} & \text { Method Period } \begin{array}{c}\text { Accumu- Reference } \\ \text { lation } \pm \sigma \\ \mathrm{g} \mathrm{cm}^{-2} \text { year }^{-1}\end{array} & \begin{array}{c}10 \mathrm{~m} \text { tem- } \\ \text { perature } \\ { }^{\circ} \mathrm{C}\end{array}\end{array}$

Cap Prud-

homme $0 \quad 0$

$\begin{array}{lll}\text { J01 } & 0.50 \quad 66\end{array}$

$\begin{array}{lll}\text { D02 } & 1.00 & \\ \text { D03 } & 1.45 & 135\end{array}$

$\begin{array}{lll}\text { L04 } & 1.80 & \\ \text { D05 } & 2.00 & 163\end{array}$

$\begin{array}{lll}\text { D05 } & 2.00 & 163 \\ \text { D04bis } & 2.35 & \\ \text { D06 } & 2.55 & 183\end{array}$

A3 183

D07 $\quad 3.10 \quad 200$

D08 $\quad 3.50 \quad 210$

D09(ex.A5) $4.20 \quad 223$

D10* $\quad 5.00 \quad 235$

D11 $\quad 5.85 \quad 241$

$\begin{array}{lll}\text { L12 } & 6.35 & 246 \\ \text { R13* } & 7.05 & 260\end{array}$

M14 $7.65 \quad 266$

$\begin{array}{lll}\text { D15 } & 8.45 & 296 \\ \text { M16 } & 9.35 & 346\end{array}$

$\begin{array}{lll}\text { E17 } & 10.45 \quad 396\end{array}$

$\begin{array}{lll}\mathrm{J} 18^{*} & 11.10 \quad 421\end{array}$

$\begin{array}{lll}\text { D19 } & 12.15 \quad 440\end{array}$

$\begin{array}{lll}\text { J.20 } & 13.20 \quad 470\end{array}$

$\begin{array}{lll}\text { D21 } & 14.15 \quad 500\end{array}$

M22 $\quad 15.20 \quad 523$

D23 $\quad 16.20 \quad 556$

L24* $\quad 17.15 \quad 565$

$\begin{array}{lll}\text { L25 } & 18.20 \quad 569\end{array}$

E26 $\quad 19.20 \quad 589$

D27 20.15 607

J28 $\quad 21.15 \quad 629$

$\begin{array}{lll}\text { L29 } & 22.15 \quad 638\end{array}$

J30 $\quad 23.15 \quad 636$

M31 $24.25 \quad 634$

D32 $25.25 \quad 662$

K33* $26.10 \quad 690$

K.34 $27.30 \quad 709$

K $35 \quad 28.20 \quad 717$

D36 $29.20 \quad 722$

$\begin{array}{lll}\text { D37 } & 30.20 \quad 737\end{array}$

K38 $\quad 31.20 \quad 752$

N39 $\quad 32.20 \quad 759$

$\mathrm{E} 40^{*}$

$33.20 \quad 783$

$132 \quad 2 \quad 5 \quad 1971-77-10 \pm 20$

$\begin{array}{rrrrr}73 & 8 & 5 & 1971-79 & -8 \pm 8\end{array}$

$\begin{array}{lllll}12 & s & 1971-83 & 3 \pm 6\end{array}$

1971-83 $9 \pm 3$

1962-83 $8 \pm 4$

$1971-83 \quad 14 \pm 5$

$1971-83 \quad 11 \pm 5$

$1956-69 \quad 22 \pm 5 \quad$ (1)

$\begin{array}{lllll}12 & S & 1971-83 & 24 \pm 5\end{array}$

$22 \quad s+B \quad 1955-83 \quad 25 \pm 6 \quad$ (2)

$\begin{array}{llllll}15 & S+\beta & 1965-83 & 13 \pm 4\end{array}$

17

12 s $\quad 1971-83 \quad 23 \pm 5$

$s+B \quad 1955-83 \quad 37 \pm 6$

s $\quad 1971-82 \quad 34 \pm 13$

S $\quad 1971-83 \quad 44 \pm 12$

$s+B \quad 1965-82 \quad 43 \pm 6$ This work -16.2

S $\quad 1971-83 \quad 98 \pm 14$

s $\quad 1972-83 \quad 8 \pm 7$

$s+B \quad 1965-83 \quad 51 \pm 7$ This work -16.5

s $\quad 1971-83 \quad 49 \pm 14$

s $\quad 1971-82 \quad 65 \pm 10$

s $\quad 1971-83 \quad 60 \pm 9$

$-17.3$

$s+B \quad 1969-83 \quad 53 \pm 7$ This work

$s+B \quad 1965-83 \quad 44 \pm 8 \quad$ (3)

$s+B \quad 1955-83 \quad 36 \pm 4$ This work -17.7

$s+B \quad 1965-83 \quad 64 \pm 7$ This work -17.6

$\begin{array}{lllll}S+B & 1955-83 & 35 \pm 5 & \text { (3) } & -17.9\end{array}$

s $\quad 1971-83 \quad 44 \pm 13$

s $\quad 1971-83 \quad 78 \pm 11$

s $1971-83 \quad 44 \pm 9$

$s+B \quad 1977-83 \quad 117 \pm 16$ This work -17.8

s $\quad 1971-83 \quad 57 \pm 9$

s $\quad 1971-82 \quad 32 \pm 11$

$s+B \quad 1955-83 \quad 13 \pm 3$

(3) -18.3

s $\quad 1971-83 \quad 45 \pm 11$

s $\quad 1971-83 \quad 94 \pm 22$

s $\quad 1971-83 \quad 77 \pm 11$

$s+B \quad 1971-83 \quad 52 \pm 16$ This work -19.1

s $\quad 1971-83 \quad 90 \pm 10$

s $\quad 1971-83 \quad 51 \pm 13$

s $\quad 1971-83 \quad 63 \pm 17$

*Stations positioned by the Doppler-effect survey.

$s$ Accumulation determined by stake measurement.

$B$ Accumulation determined by $\beta$ radioactivity.

References

1. Lorius and others, 1970

2. Lambert and others, 1977.

3. Pourchet and others, 1983. 
TABLE IV. MEAN ANNUAL TEMPERATURE AT DUMONT D'URVILLE COMPARED TO MEAN ANNUAL ACCUMULATION BETWEEN D10 TO D21

Year

$$
\begin{gathered}
\text { Mean accumulation between } \\
\text { D10 and D21 } \\
\mathrm{g} \mathrm{cm}^{-2} \mathrm{year}^{-1}
\end{gathered}
$$

Mean annual temperature at Dumont d'Urville

1971

1972

1973

1974

1975

1976

1977

1978

1979

1980

1981

1982

$\begin{array}{ll}66 & -10.0 \\ -6 & -9.9 \\ 68 & -10.3 \\ 44 & -10.8 \\ 50 & -11.0 \\ 80 & -11.2 \\ 18 & (-10.2) \\ 38 & -10.4 \\ 47 & -10.9 \\ 36 & -9.8 \\ 65 & -8.7 \\ 37 & -10.3\end{array}$

explained by the relief. On the other hand, the temporal variations are quite homogeneous from one stake to another, but these variations are not governed simply by temperatures.

\section{Beyond stake E40}

Table $\mathrm{V}$ gives all the relevant data available for this area. For each accumulation figure, we give a mean standard deviation ( $\sigma$ ) corresponding to the $90 \%$ annual variability we measured in the preceding area.

From stake E40 (Fig. 7), a continuous decrease in accumulation $(A)$ is observed when plotted against the distance to the coast. This decrease can be expressed by

$$
A=y_{\mathrm{e}}^{\omega x}
$$

where $x$ is the distance to E40, and $\gamma$ and $\omega$ are two constants. When $A$ is expressed in $\mathrm{g} \mathrm{cm}^{-2}$ year $^{-1}$ and $x$ in $\mathrm{km}$, we find

$$
\begin{aligned}
& y=40.3 \mathrm{~g} \mathrm{~cm}^{-2} \text { year }^{-1} \\
& \omega=-248 \times 10^{-5} \mathrm{~km}^{-1} .
\end{aligned}
$$

Between E40 and R60, large cyclic variations are superimposed on a decreasing mean trend. For this area, the accumulation $(Y)$ can be expressed by the product of two factors: a decreasing $(A)$ governed mainly by temperature and a deviation $(B)$ associated with a wave function that can be expressed:

$$
Y=A B .
$$

This correcting term $(B)$ is given by

$$
B=1+\delta \sin (\alpha x+\beta) \text {. }
$$

In our case we find

$$
\begin{aligned}
& B \neq 0, \\
& \alpha=120 / 13 \mathrm{~km}^{-1}, \\
& \delta \neq 0.3 .
\end{aligned}
$$

The complete expression of the accumulation between E40 and R60 becomes

$$
Y=(40.3 \exp -0.00248 x)(1+0.3 \sin 120 x / 13) .
$$

These periodic oscillations in the accumulation revealed between E40 and R60 cannot be explained by a simple relationship with the relief as seems to be the case in the vicinity of Wilkes Station (Black and Budd, 1964). We suggest a meteorological explanation for this phenomenon.
METEOROLOGICAL ANALYSIS ACCUMULATION OSCILLATIONS

OF

OBSERVED

\section{Outline of the problem}

The above results show that from the point of break in slope of the Antarctic plateau, near stake R60, the accumulation of snow (which is almost uniform on this plateau) changes in a periodic manner with distance, until reaching the coastal area, with a quasi-constant wavelength of about $40 \mathrm{~km}$.

In this area there is no melting of snow. The accumulation of snow therefore represents roughly the annual precipitation. However, the spatial distribution can be non-uniform due to the combined effects of wind and relief, which will now be discussed.

\section{Precipitation conditions}

In order to establish the most frequently occurring conditions of precipitation in the Terre Adélie area, we use the data collected during the International Geophysical Year $(1957-58)$. This information is quite old but it is more continuous and better documented than data collected from automatic weather stations installed since the I.G.Y. In particular, the Charcot meteorological weather station (lat. $69^{\circ} 22^{\prime}$ S., long. $139^{\circ} 01^{\prime}$ E., $2400 \mathrm{~m}$ elevation) was operational during the I.G.Y. period, next to the break-in-slope location. This location is ideal for an appreciation of the meteorological conditions both on the plateau and at the summit of the slope line.

On the other hand, the climate at the permanent Dumont d'Urville meteorological station is largely influenced by the ocean and by the katabatic winds.

Table VI shows that in winter (April-September) at Charcot, the number of days of blowing snow is always higher than the number of days of snowfall. This confirms the idea that wind plays a major role in spreading the snow accumulation. Furthermore, the number of days of blowing snow at Charcot is higher than at Dumont d'Urville. This strong contrast can be explained by the fact that Dumont d'Urville is influenced by oceanic conditions and that in the case of katabatic wind, the hydraulic jump, physically described as the "blowing-snow wall" (Valtat, 1960), which greatly reduces the strength of the surface wind, often occurs on the slope up-stream of Dumont d'Urville.

\section{Snow transport by wind}

The snow is transported by wind, either during precipitation or by uplift from the surface by turbulence. Figure 8 shows the probability of finding snow particles in suspension in the air as a function of wind speed at a height of $10 \mathrm{~m}$ (Radok, 1968). In order to define this curve, the author assumed that the mean snowfall speed, in the proximity of the surface, was $0.3 \mathrm{~m} / \mathrm{s}$. This value was determined from measurements conducted at Byrd Station (Antarctica) and corresponds well to the type of snow falling on the well studied area. Moreover, these measurements have shown that the average fall speed near the surface is weakly dependent on the horizontal wind strength.

At a wind speed of $5 \mathrm{~m} / \mathrm{s}, 10 \%$ of upward currents already exceed the fall speed of the snow. At Charcot, curtains of blowing snow were observed in spite of wind speeds no greater than $5 \mathrm{~m} / \mathrm{s}$ (Garcia, 1960). If the wind is greater than $20 \mathrm{~m} / \mathrm{s}, 70 \%$ of upward currents exceed the fall speed. Table VII shows the mean values of the main meteorological features at Charcot Station in 1958. Over the year, there is a total of 326 days of blowing snow. The monthly mean wind speed is never less than $6.9 \mathrm{~m} / \mathrm{s}$. The monthly maximum wind speeds are always greater than or equal to $20 \mathrm{~m} / \mathrm{s}$, except in February $(15 \mathrm{~m} / \mathrm{s})$.

Table VI shows that in 1957 the number of days of blowing snow was less (261). But, even if 1958 was an exceptional year, we can still conclude that deposition of snow occurs mainly under strong wind conditions.

Generally, there are two modes of snow transport by wind (Male, 1980): 
TABLE V. OBSERVATIONS AND MEASUREMENTS BETWEEN STAKE E40 AND DOME C

\begin{tabular}{|c|c|c|c|c|c|c|c|c|c|}
\hline \multirow{2}{*}{$\begin{array}{l}\text { Station } \\
\text { D41 }\end{array}$} & \multirow{2}{*}{$\begin{array}{c}\text { Distance } \\
\text { to } E 40 \\
\mathrm{~km} \\
9\end{array}$} & \multirow{2}{*}{$\begin{array}{l}\text { Altitude } \\
\text { m } \\
924\end{array}$} & \multirow{2}{*}{$\begin{array}{c}\text { Number } \\
\text { of years } \\
10\end{array}$} & Method & Period & \multicolumn{2}{|c|}{$\begin{array}{l}\text { Accumu- } \\
\text { lation } \\
\mathrm{g} \mathrm{cm}^{-2} \text { year }^{-1}\end{array}$} & Reference & \multirow{2}{*}{$\begin{array}{c}10 \text { m temper } \\
\text { ature } \\
{ }^{\circ} \mathrm{C} \\
-19.8\end{array}$} \\
\hline & & & & $s+B$ & $1965-78$ & 60 & \pm 18 & (2) & \\
\hline J41 & 12 & 965 & 7 & B & $1969-76$ & 70 & \pm 29 & (2) & -21.0 \\
\hline D42 & 18 & 1028 & 23 & $s+B$ & $1955-83$ & $32=$ & \pm 6 & (3) & \\
\hline D43 & 27 & 1143 & 21 & B & $1955-76$ & $24=$ & \pm 5 & (3) & -22.6 \\
\hline N44 & 37 & 1263 & 5 & s & $1972-83$ & 30 & \pm 14 & & \\
\hline D45 & 47 & 1353 & 23 & $S+B$ & $1955-83$ & 42 & \pm 8 & (2) & -24.0 \\
\hline D46 & 57 & 1456 & 8 & $s$ & $1972-83$ & 56 & \pm 19 & & \\
\hline $\mathrm{N} 47^{*}$ & 68 & 1524 & 26 & $s+B$ & $1955-83$ & $26=$ & \pm 5 & (3) & -25.8 \\
\hline D48 & 78 & 1594 & 4 & s & $1972-76$ & $32=$ & \pm 17 & & \\
\hline D49 & 88 & 1659 & 6 & s & $1972-83$ & $41=$ & \pm 16 & & \\
\hline N50 & 98 & 1709 & 25 & $s+\beta$ & $1955-83$ & $24=$ & \pm 4 & (2) & -27.6 \\
\hline D51 & 108 & 1769 & 11 & s & $1972-83$ & 22 & \pm 6 & & \\
\hline D52* & 118 & 1831 & 11 & s & $1972-83$ & $25=$ & \pm 7 & & \\
\hline D53 & 128 & 1898 & 28 & $s+B$ & $1955-83$ & 36 & 6 & (3) & -29.8 \\
\hline D54 & 138 & 1927 & 11 & s & $1972-83$ & $31=$ & \pm 9 & & $-29 . .8$ \\
\hline $\mathrm{D} 55 \mathrm{~N}$ & 143 & 1963 & 13 & B & $1965-78$ & $13-2$ & $20 \pm 4$ & This work & \\
\hline D55 & 148 & 1995 & 28 & $s+B$ & $1955-83$ & 8 & \pm 2 & This work & \\
\hline D55* & 140 & 1990 & 28 & $S+B$ & $1955-83$ & 5 & 1 & (3) & -31.1 \\
\hline D55S & 153 & 2053 & 13 & B & $1965-78$ & 16 & 4 & This work & \\
\hline D56 & 158 & 2063 & 11 & s & $1972-83$ & $33=$ & 9 & & -31.0 \\
\hline D57N & 163 & 2052 & - & - & & & & & \\
\hline D57* & 168 & 2071 & 18 & $s+\beta$ & $1965-83$ & 41 & \pm & This work & -31.6 \\
\hline D57S & 173 & 2120 & - & - & & & & & \\
\hline D58 & 178 & 2149 & 4 & s & $1972-76$ & $29=$ & \pm 15 & & -32.6 \\
\hline D58S & 183 & 2200 & 26 & B & $1955-81$ & 4 & \pm 1 & This work & \\
\hline 590 & 184 & & 5 & s & $1978-83$ & 14 & \pm 7 & & \\
\hline D59* & 188 & 2228 & 28 & $S+B$ & $1955-83$ & 32 & \pm 5 & (2) & -34.3 \\
\hline $\mathrm{R} 60^{*}$ & 201 & 2291 & 21 & B & $1955-76$ & 26 & \pm 7 & (2) & -36.3 \\
\hline D61 & 211 & 2299 & 4 & s & $1972-76$ & 33 & \pm 7 & & \\
\hline D62 & 221 & 2318 & 4 & s & $1972-76$ & 27 & \pm 14 & & -37.9 \\
\hline D63 & 231 & 2316 & 4 & s & $1972-76$ & 25 & \pm 13 & & \\
\hline D64 & 241 & 2333 & 4 & s & $1972-76$ & 21 & \pm 11 & & \\
\hline $\mathrm{R} 65^{*}$ & 251 & 2334 & 1 & s & $1972-73$ & 25 & \pm 23 & & \\
\hline D66 & 261 & 2357 & 18 & $s+B$ & $1955-73$ & 20 & \pm 4 & (2) & -38.8 \\
\hline D67 & 272 & 2372 & 1 & s & $1972-73$ & 20 & \pm 18 & & \\
\hline D68 & 282 & 2379 & 1 & s & $1972-73$ & 19 & \pm 18 & & \\
\hline D69 & 293 & 2379 & 1 & s & $1972-73$ & 26 & \pm 23 & & \\
\hline R70* & 303 & 2395 & 1 & $\mathbf{s}$ & $1972-73$ & 15 & \pm 13 & & \\
\hline D71 & 313 & 2407 & 1 & s & $1972-73$ & 9 & \pm 8 & & \\
\hline D72 & 324 & 2412 & 18 & B & $1955-73$ & 23 & \pm 7 & (2) & -41.2 \\
\hline D73 & 334 & 2408 & 1 & s & $1972-73$ & 11 & \pm 10 & & \\
\hline D74 & 345 & 2423 & 1 & s & $1972-73$ & 15 & \pm 13 & & \\
\hline R75* & 355 & 2436 & 1 & s & $1972-73$ & 13 & \pm 12 & & \\
\hline D76 & 364 & 2435 & 1 & s & $1972-73$ & 18 & \pm 16 & & \\
\hline D77 & 373 & 2407 & 1 & s & $1972-73$ & 22 & \pm 20 & & \\
\hline D78 & 382 & 2477 & 1 & s & $1972-73$ & 12 & \pm 10 & & \\
\hline D79 & 391 & 2479 & 1 & s & $1972-73$ & 16 & \pm 14 & & \\
\hline $\mathrm{R} 80^{*}$ & 399 & 2487 & 28 & B & $1955-83$ & 24 & \pm 4 & This work & -41.4 \\
\hline D100 & 600 & & 17 & B & $1955-72$ & 13 & \pm 3 & (2) & -46.3 \\
\hline D120 & 800 & & 17 & B & $1955-72$ & 8 & \pm 2 & (2) & -52.3 \\
\hline Dome C & 1040 & 3240 & 25 & B & $1955-80$ & 3.2 & \pm 0.6 & (4) & -53.5 \\
\hline
\end{tabular}

*Stations positioned by the Doppler-effect survey.

\section{References}

2. Lambert and others, 1977

3. Pourchet and others, 1983

4. Petit and others, 1982 .

Saltation. Within a $10 \mathrm{~cm}$ thick layer above the surface, the snow particles follow a curved trajectory under the influence of gravity and the drag force resulting from the relative speed between the wind and the particles (Fig. 9).

Diffusion. When the wind reaches a certain level, the particles are transported in suspension in the air by turbulent diffusion.

In either case, experience shows that, due to inhomogeneities of the medium and the surface beneath, the travel distance of the particles is low, around a few meters, and that they give rise to low-height undulations on the surface.

Dunes. We assume that dunes are built up in the same way as undulations (Dallavalle, 1948). The heavier particles build up at the top of undulations until they form ridges and then dunes when the wind frequently blows in the same direction. The undulation wavelength depends on the wind strength and increases together with their crest height.
Effect of relief. The effect of relief on the accumulation of snow has not been studied for the relevant scale (about $50 \mathrm{~km}$ in horizontal distance). On a small scale (small hills or buildings), snow is known to deposit on the wind-protected side (Radok, 1977).

However, Figure 10 (Dallavalle, 1948) demonstrates that in the dune travel mechanism, the particles accumulate on the exposed side instead of in the hollows between undulations.

Thus, hills do not fill in but move instead, very slowly, in the direction opposite to that of the prevailing wind.

Experimental remarks. In the area of interest, there is a strong correlation between the isotope content of the snow and the mean annual temperature of the related location (Lorius and Merlivat, 1977). The isotope content varies linearly with the distance from the coast. These observations are incompatible with snow transport by wind, heterogeneous by nature, over long distances (exceeding $10 \mathrm{~km})$. 


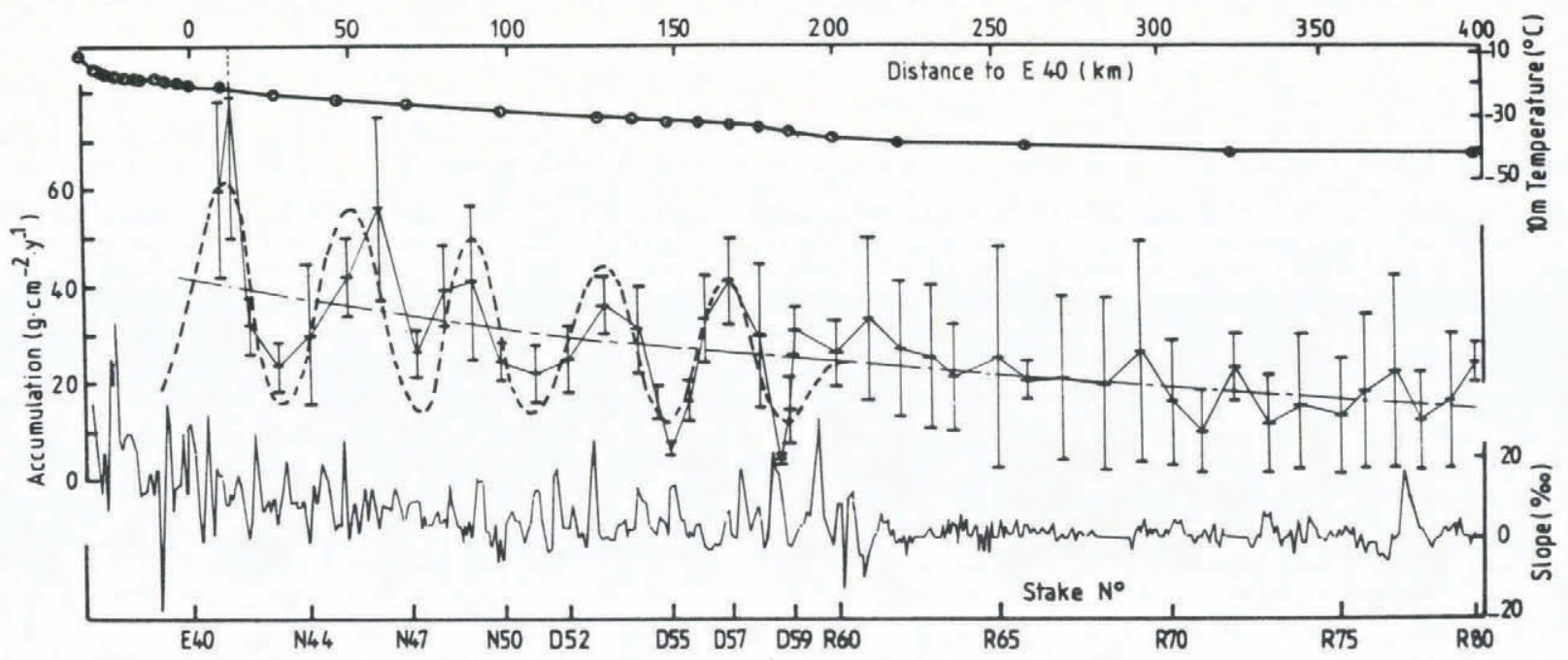

Fig. 7. Variations of three parameters along the Dumont d'Urville-R80 axis. Upper curve: $10 \mathrm{~m}$ depth snow temperature. Middle curve: accumulation measurement for the longest period observed. Individual measurement. Accumulation explained by temperature variations. --- Accumulation explained by temperature variations and wave function. The 10 uncertainties associated with individual measurements are given by the number of years of observation. Lower curve: $1 \mathrm{~km}$ mean slope along the Dumont d'Urville-R80 axis.

TABLE VI. NUMBER OF DAYS OF SNOWFALL AND SNOW-BLOW AT DUMONT D'URVILLE AND CHARCOT DURING THE INTERNATIONAL GEOPHYSICAL YEAR (195758) (AFTER CORNET AND OTHERS, 1960)

\begin{tabular}{lcccccccccccccc}
\multicolumn{2}{l}{$\begin{array}{l}\text { Dumont d'Urville } \\
\text { Snowfall }\end{array}$} & $J$ & $F$ & $M$ & $A$ & $M$ & $J$ & $J$ & $A$ & $S$ & $O$ & $N$ & $D$ & Total \\
& 1957 & 13 & 10 & 12 & 12 & 8 & 10 & 11 & 9 & 9 & 8 & 14 & 8 & 124 \\
& 1958 & 15 & 9 & 18 & 12 & 4 & 5 & 12 & 15 & 8 & 11 & 7 & 8 & 124 \\
Snow-blow & 1957 & 1 & 5 & 9 & 18 & 12 & 15 & 18 & 15 & 16 & 15 & 6 & 1 & 131 \\
& 1958 & 6 & 4 & 19 & 14 & 6 & 10 & 11 & 19 & 15 & 11 & 7 & 6 & 128
\end{tabular}

Charcot

$\begin{array}{lrrrrrrrrrrrrrr}\text { Snowfall } & 1957 & \mathrm{x} & \mathbf{x} & \mathbf{3} & 3 & 3 & 0 & 2 & 3 & 2 & 2 & 5 & 5 & 28 \\ & 1958 & 8 & 4 & 12 & 10 & 8 & 4 & 15 & 15 & 1 & 7 & 4 & 8 & 96^{*} \\ & & & & & & & & & & & & & & \\ \text { Snow-blow } & 1957 & \mathrm{x} & \mathrm{x} & 20 & 28 & 25 & 30 & 27 & 28 & 28 & 29 & 27 & 19 & 261 \\ & 1958 & 25 & 24 & 30 & 29 & 29 & 30 & 28 & 28 & 30 & 29 & 23 & 21 & 326^{\dagger}\end{array}$

* 84 from March to December.

$\dagger_{271}$ from March to December.

A comparison of the curves in Figure 7 shows that snow accumulation and the slope of the surface, as a function of distance from the coast, are not correlated.

We observe a strong contrast between the plateau, where accumulation is relatively uniform and slopes are shallow, and the slope area, where accumulation takes on a cyclic mode and slopes are steep.

Conclusion. These last three observations allow us to conclude that the mechanisms described previously can explain undulation formation with a wavelength up to about $10 \mathrm{~km}$.

However, the redistribution of snow by wind in such a way cannot occur on a sufficient scale to explain the cyclic mode of snow accumulation with a wavelength of $40 \mathrm{~km}$.

We must therefore seek a large-scale atmospheric phenomenon causing the modification of snow deposition Such a phenomenon could be an atmospheric wave inducing "lift-up" or "fall-down" areas. These two distinct areas could locally inhibit or enhance snowfall, which would then be deposited in a non-uniform manner on the surface.

However, each system must respect certain special conditions: the wind must have an almost uniform direction and be of sufficient strength; the atmospheric wavelength must be almost constant and the disturbance must be triggered by the "break in slope". 


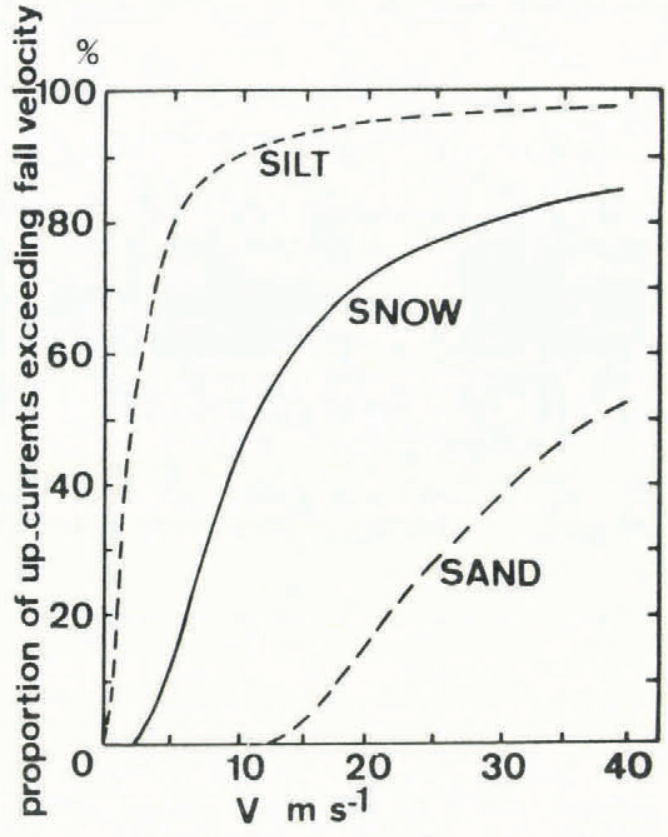

Fig. 8. Cumulative frequency curves of suspension up-currents for silt, snow, and sand (after Radok, 1968).

\section{Determination of the system of equations}

The aim is to establish a system of equations relative to the given problem allowing us to study the conditions for the formation of a gravity-inertia wave.

Antarctic climatology shows that, due to temperature differences between the continent and the sea, an eastward circulation prevails in the low troposphere, from the surface up to $3000 \mathrm{~m}$ (Alt, 1960).

Resulting from this, and in the area of interest, the winds mainly show a constant direction, satisfying one of the wind conditions and reducing the problem to two dimensions.

Observations show that katabatic winds are very frequent in this area (Valtat and others, 1960).

We can therefore assume that the second condition, strong winds, will generally be satisfied. A katabatic wind is induced by a cold (dense) air flow, caused by gravity in

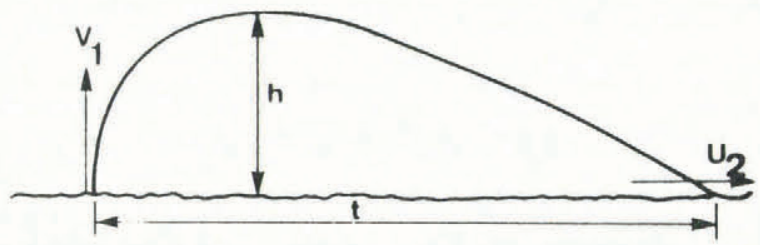

Fig. 9. Trajectory of a particle during saltation (after Male, 1980).

the direction of the slope. Over the cold air layer is warmer air separated from the former by a fluid interface, and generated in the atmosphere by a thin temperature inversion layer.

This type of flow can be studied using the two-layer model proposed by Ball (1956). However, because of the horizontal scale involved (in the order of $100 \mathrm{~km}$ ) and the proximity of the South Pole, we cannot neglect Coriolis force effects. Once again, based on a two-layer model, the effects of the Coriolis force have been studied by Ball (1960) and by Gutman and Khain (1975).

In the following sections, we shall follow these works but restrict ourselves to the study of the conditions of formation of gravity-inertia waves in the area of interest.

Equations. We choose the case causing the flow of two fluids of different densities superimposed and separated by an interface (Fig. 11),$\rho_{0}$ is the density of the upper fluid, $\rho_{1}$ is that of the lower fluid, $h$ is the height of the interface measured up from the surface, and $\delta$ is the height relative to the $x-y$ plane.

The $Y$-axis is perpendicular to the plane of Figure 11 . We assume that the problem can be reduced to two dimensions by invariance perpendicular to the $x-z$ plane.

At elevation $H$ in the upper fluid, the atmospheric

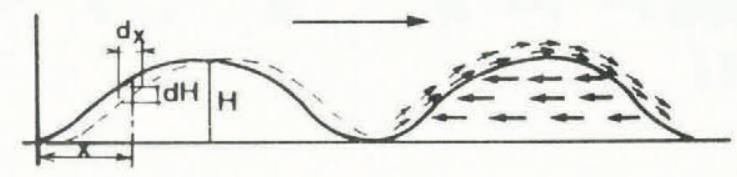

Fig. 10. Schematic illustration of dune travel (after Dallavalle, 1948).

TABLE VII. METEOROLOGICAL DATA DURING THE INTERNATIONAL GEOPHYSICAL YEAR (1957-58) AT CHARCOT (lat. $69^{\circ} 22^{\prime}$ S., long. $139^{\circ} 01^{\prime}$ E., $2400 \mathrm{~m}$ altitude)

\begin{tabular}{|c|c|c|c|c|c|c|c|c|c|c|c|c|c|}
\hline & Jan. & Feb. & Mar. & Apr. & May & Jun. & Jul. & Aug. & Sept. & Oct. & Nov. & Dec. & Year \\
\hline $\begin{array}{l}\text { Mean temperature }\left({ }^{\circ} \mathrm{C}\right) \\
\text { Minimum } \\
\text { Maximum }\end{array}$ & $\begin{array}{l}-22.1 \\
-31.0 \\
-10.7\end{array}$ & $\begin{array}{l}-30.6 \\
-44.2 \\
-20.4\end{array}$ & $\begin{array}{l}-34.4 \\
-43.8 \\
-15.0\end{array}$ & $\begin{array}{l}-38.5 \\
-55.2 \\
-21.0\end{array}$ & $\begin{array}{l}-41.4 \\
-54.9 \\
-14.0\end{array}$ & $\begin{array}{l}-49.8 \\
-61.5 \\
-27.0\end{array}$ & $\begin{array}{l}-41.7 \\
-61.5 \\
-17.6\end{array}$ & $\begin{array}{l}-43.2 \\
-60.2 \\
-19.6\end{array}$ & $\begin{array}{l}-51.6 \\
-61.5 \\
-40.9\end{array}$ & $\begin{array}{l}-30.7 \\
-55.7 \\
-16.9\end{array}$ & $\begin{array}{l}-30.5 \\
-42.0 \\
-20.3\end{array}$ & $\begin{array}{l}-23.7 \\
-33.5 \\
-17.1\end{array}$ & $\begin{array}{l}-37.3 \\
-51.1 \\
-21.5\end{array}$ \\
\hline $\begin{array}{l}\text { Mean pressure (1/10 mbar) } \\
\text { Minimum } \\
\text { Maximum }\end{array}$ & $\begin{array}{l}730.0 \\
718.5 \\
743.2\end{array}$ & $\begin{array}{l}726.3 \\
717.6 \\
734.6\end{array}$ & $\begin{array}{l}225.3 \\
710.5\end{array}$ & $\begin{array}{l}724.7 \\
713.7 \\
739.6\end{array}$ & $\begin{array}{l}728.4 \\
707.3 \\
752.3\end{array}$ & 738.5 & $\begin{array}{l}725.5 \\
698.4 \\
741.6\end{array}$ & $\begin{array}{l}715.5 \\
697.4 \\
735.6\end{array}$ & $\begin{array}{l}706.9 \\
692.9 \\
725.2\end{array}$ & $\begin{array}{l}715.9 \\
695.5 \\
733.0\end{array}$ & $\begin{array}{l}721.1 \\
744.5 \\
731.9\end{array}$ & $\begin{array}{l}724.2 \\
713.0 \\
734.7\end{array}$ & $\begin{array}{l}721.1 \\
705.0 \\
735.5\end{array}$ \\
\hline Relative humidity (\%) & & 65 & 73 & 75 & 75 & 73 & 75 & 76 & 72 & 71 & 66 & 68 & 71 \\
\hline $\begin{array}{l}\text { Average wind speed }(\mathrm{m} / \mathrm{s}) \\
\text { Maximum } \\
\text { Prevailing direction }\end{array}$ & $\begin{array}{r}9.4 \\
24 \\
150^{\circ}\end{array}$ & $\begin{array}{c}8.9 \\
15 \\
180^{\circ}\end{array}$ & $\begin{array}{l}10.8 \\
26 \\
160^{\circ}\end{array}$ & $\begin{array}{l}10.9 \\
26 \\
160^{\circ}\end{array}$ & $\begin{array}{r}8.0 \\
20 \\
170^{\circ}\end{array}$ & $\begin{array}{l}11.9 \\
29^{\circ} \\
170^{\circ}\end{array}$ & $\begin{array}{c}8.4 \\
23 \\
200^{\circ}\end{array}$ & $\begin{array}{r}8.1 \\
27 \\
170^{\circ}\end{array}$ & $\begin{array}{l}10.5 \\
26 \\
170^{\circ}\end{array}$ & $\begin{array}{c}8.7 \\
21 \\
170^{\circ}\end{array}$ & $\begin{array}{c}7.8 \\
20^{\circ} \\
155^{\circ}\end{array}$ & $\begin{array}{c}6.9 \\
26 \\
150^{\circ}\end{array}$ & $\begin{array}{r}9.2 \\
23.8^{\circ} \\
170^{\circ}\end{array}$ \\
\hline Mean 700 mbar elevation & 2710 & 2671 & 2632 & 2643 & 2674 & 2527 & 2645 & 2555 & 2169 & 2559 & 2615 & 2651 & 2614 \\
\hline Snow-blow days & 25 & 24 & 20 & 29 & 29 & 30 & 28 & 28 & 30 & 29 & 23 & 21 & 326 \\
\hline Fog & & 13 & 24 & 30 & 25 & 29 & 25 & 25 & 30 & 18 & 10 & 10 & 239 \\
\hline Snow & 8 & 4 & 12 & 10 & 8 & 4 & 15 & 15 & 1 & 7 & 4 & 8 & 96 \\
\hline Rime & 1 & 0 & 1 & 3 & 4 & 2 & 4 & 2 & 0 & 0 & 4 & 0 & 21 \\
\hline Aurora & 0 & 0 & 0 & 1 & 5 & 0 & 6 & 5 & 1 & 0 & 0 & 0 & 18 \\
\hline Ice crystals & 0 & 0 & 0 & 0 & 0 & 0 & 1 & 2 & 1 & 2 & 0 & 0 & 6 \\
\hline
\end{tabular}




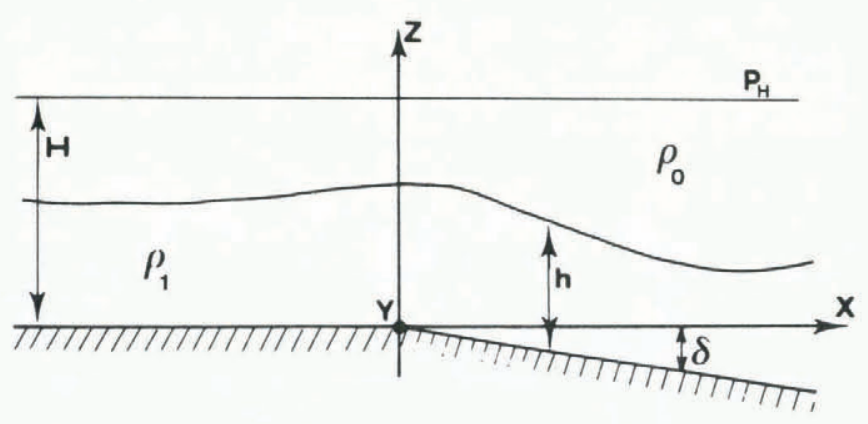

Fig. 11. Air flow beneath an inversion layer. The base of the inversion is idealized as an interface between two fluids of different densities $\rho_{0}$ and $\rho_{1}$.

pressure is $P_{\mathrm{H}}$ and we assume that geostrophic equilibrium is established, expressed as:

$$
\begin{aligned}
& v_{\mathrm{g}}=-\frac{1}{\rho_{0}} f \frac{\partial P_{\mathrm{H}}}{\partial y}=\text { constant } \\
& v_{\mathrm{g}}=-\frac{1}{\rho_{0}} f \frac{\partial P_{\mathrm{H}}}{\partial x}=\text { constant. }
\end{aligned}
$$

The hydrostatic equation allows us to express the pressure $P_{1}$ in the lower layer, at a height $Z$, as

$$
P_{1}=P_{\mathrm{H}}+\rho_{0} g H+\left(\rho_{1}-\rho_{0}\right) g(h+\delta)-\rho_{1} g z .
$$

The standing-wave equations can be written

$$
\begin{gathered}
u \frac{\mathrm{d} u}{\mathrm{~d} x}=-\frac{\rho_{1}-\rho_{0}}{\rho_{1}} g \mathrm{~d} \frac{h+\delta}{\mathrm{d} x}+f\left(v-V_{\mathrm{g}}\right) \\
u \frac{\mathrm{d} v}{\mathrm{~d} x}=f\left(V_{\mathrm{g}}-u\right) \\
\frac{\mathrm{d} u}{\mathrm{~d} x} h=0
\end{gathered}
$$

where $f$ is the Coriolis parameter, $u$ and $v$ are the horizontal components of the speed respectively in directions $x$ and $y$. We can write the expressed variables in a dimensionless form by introducing a critical speed $U_{\mathrm{c}}=\left(g^{\prime} Q\right)^{1 / 3}$ where $Q=U h=$ constant and

$$
g^{\prime}=\frac{\rho_{1}-\rho_{0}}{\rho_{0}}=\frac{\Delta \theta}{\theta} g
$$

where $\Delta \theta$ is the potential temperature difference between the cold air layer of temperature $\theta$ which flows down the slope and the warmer air which is on top.

The dimensionless variables, with a bar over them, are expressed by

$$
x=\frac{U_{\mathrm{c}}}{f} \bar{x} ; \quad u=U_{\mathrm{g}} \bar{u} ; \quad v=V_{\mathrm{g}}=U_{\mathrm{c}} \bar{v}
$$

and

$$
z=\frac{U_{\mathrm{c}}{ }^{2}}{g^{\prime}} \bar{z}
$$

Then the system of Equations (3) is written in dimensionless form, omitting the bars:

$$
\begin{gathered}
\propto \frac{\mathrm{d} u}{\mathrm{~d} x}+\frac{\mathrm{d} h}{\mathrm{~d} x}+\frac{\mathrm{d} \delta}{\mathrm{d} x}=v \\
u \frac{\mathrm{d} v}{\mathrm{~d} x}=1-u \\
u h=1
\end{gathered}
$$

where

$$
\alpha=\left[\frac{U_{\mathrm{g}}}{U_{\mathrm{c}}}\right]^{2}
$$

is the dimensionless parameter for the problem which depends on a Froude number. In fact,

$$
\alpha^{3 / 2}=\frac{U_{\mathrm{g}}}{u} F^{2} \text { where } F=\frac{U_{\mathrm{g}}}{\sqrt{g^{\prime} h}} .
$$

The relief is expressed in a simple way in accordance with Figure 11.

$$
\begin{array}{ll}
x<0 & \delta=0 \\
x>0 & \delta=k x .
\end{array}
$$

In the system of Equations (4), $h$ can be eliminated, and the system becomes, for $x>0$ :

$$
\begin{gathered}
\propto u \frac{d u}{d x}-\frac{1}{u^{2}} \frac{\mathrm{d} u}{\mathrm{~d} x}+k=v \\
u \frac{\mathrm{d} v}{\mathrm{~d} x}=1-u .
\end{gathered}
$$

This system in Equations (5) can be integrated:

$$
v=k \pm\left[\left(\frac{1-u}{u}\right)^{2}\left(1-\propto u^{2}\right)+C\right]^{1 / 2}
$$

where $C$ is an integration constant.

We are looking for the periodic behavior of the vertical component of speed $W$. Based on the assumption made earlier, $W$ can be written, for $z=h$, as

$$
W=u \frac{\mathrm{d} h}{\mathrm{~d} x}
$$

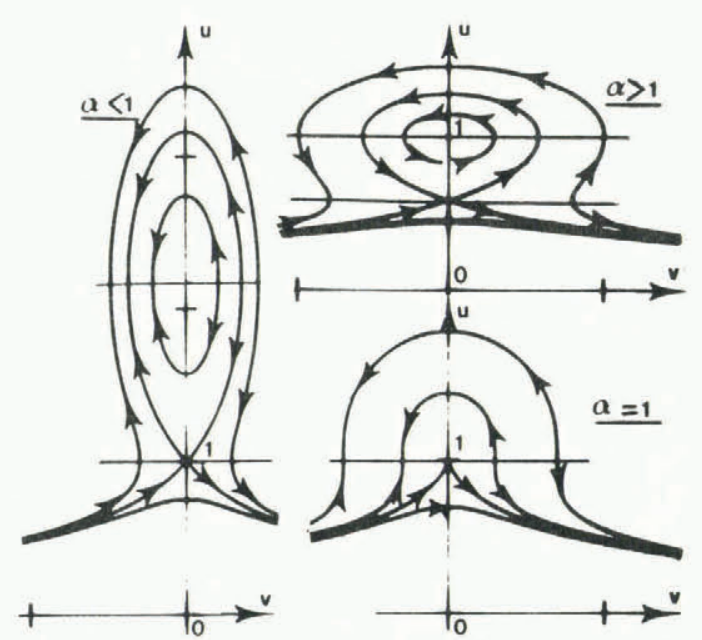

Fig. 12. Schematic representation of possible phase-plan variants. 
Because of the continuity equation of system (3), we can express $W$ as

$$
W=-h \frac{\mathrm{d} u}{\mathrm{~d} x}
$$

The $\mathrm{d} u / \mathrm{d} x$ expression we could obtain, using Equations (5) and (6), would be too complicated to demonstrate easily its periodic behavior along the $x$-axis. However, we know that if $u$ shows a periodic behavior along the $x$-axis, then the same holds for $\mathrm{d} u / \mathrm{d} x$ and consequently for $W$.

We can study graphically the behavior of $u$ and $v$ deduced from Equation (6). Three cases are to be considered:

$$
\alpha<1, \alpha=1 \text {, and } \alpha>1 \quad \text { (Fig. 12). }
$$

The curves are drawn with $k=0$. Curves corresponding to different values of $k$ may be obtained by a translation on the $v$-axis.

The arrows show the movement for increasing values of $x$, and are obtained by studying the sign of the following equations:

$$
\begin{aligned}
& \mathrm{d} u=v \frac{u^{2}}{\propto u^{3}-1} \mathrm{~d} x \\
& \mathrm{~d} v=\left[\frac{1}{u}-1\right] \mathrm{d} x .
\end{aligned}
$$

The case where $\alpha>1$ is the only one giving a closed curve with a continuous movement, i.e. with the arrows always in the same direction.

In this case, where $\alpha>1, u$ and $v$ vary periodically along the $x$-axis, around an equilibrium point $u=1$ and $v=0$. In the following sections, we only consider this case, excluding the others.

Wavelength. Figure 13 shows the graphical solution of Equation (6) for the case of $\alpha>1$ and $k<0$.

When $x<0$, there is an unique solution: $u=1$ and $V=0$, designated as point $a$, which corresponds to geostrophic balance. For $x=0$, as $|k|$ increases, we obtain ellipses increasing in size and centred around the point $v=k$ and $u=1$, corresponding to different waves as long as the curve is closed.

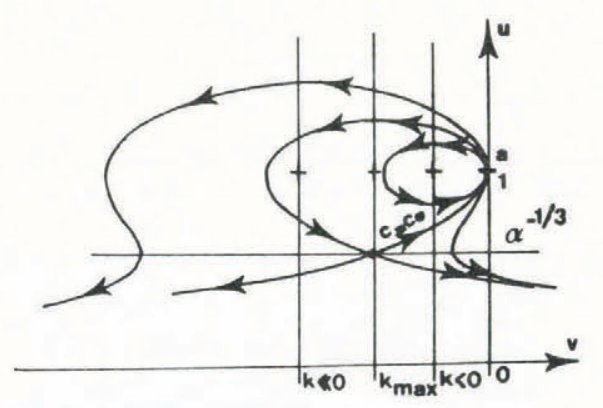

Fig. 13. Schematic representation of phase-plan integral curves used to construct the wave solution of the problem $(\alpha>1)$.

The maximum value of the periodic solution is reached when the solution crosses a singular point: $v=k_{\max }$ and $u=\alpha^{-1 / 3}$, which corresponds to a value of the integration constant:

$$
c=c_{0}=\left(\alpha^{1 / 3}-1\right)^{3} .
$$

If $|k|$ is greater than $\left|k_{\max }\right|=c_{0}{ }^{1 / 2}=\left(\alpha^{1 / 3}-1\right)^{3 / 2}$, the curve is not closed and there is no periodic solution.
In this case, the maximum amplitude of the wave is obtained for $v=k, u=\alpha^{-1 / 3}$. Then we can integrate Equations (7) between the two values where $v=k$, and we obtain the wavelength:

$$
\lambda_{0}=2 \quad \int_{\alpha^{-1 / 3}} \frac{\alpha^{2 / 3} u^{2}+\alpha^{1 / 3} u+1}{u\left[1+2\left(\alpha^{1 / 3}-1\right) u-\alpha^{-1 / 3} u^{2}\right]^{1 / 2}} \mathrm{~d} u .
$$

Otherwise, we can assume that the amplitude of oscillation is small and that we remain near geostrophic equilibrium. In this case, the graphical solution is a small ellipse centred at the point: $v=0, u=1$.

A simple analytical solution can be obtained by linearization of the system of Equations (7), which becomes

$$
\begin{gathered}
(\alpha-1) \mathrm{d} u / \mathrm{d} x=v \\
\mathrm{~d} v / \mathrm{d} x=1-u .
\end{gathered}
$$

$v$ can be removed from these two equations, giving

$$
(\alpha-1) \mathrm{d}^{2} u / \mathrm{d} x^{2}=1-u .
$$

We write $u-1=A \cos \left(2 \pi / \bar{\lambda}_{0}\right) x$, where $A$ is a constant and $\bar{\lambda}_{0}$ is the $\lambda_{0}$ dimensionless wavelength

$$
\overline{\lambda_{0}}=2 \pi(\alpha-1)^{1 / 2} \text {. }
$$

Return to dimensional values and discussion. To explain the cyclic variation of the accumulation of snow along a slope by an atmospheric wave, the atmospheric wavelength $\lambda_{0}$ must be of the same order of magnitude as the wavelength of accumulation observed at the surface, i.e. $\lambda_{0}=4 \times 10^{4} \mathrm{~m}$. Ball (1960) has shown that the wavelengths for the low-amplitude solution (Equation (10)) and for the long-amplitude solution (Equation (8)) are very close to each other.

So we can write the dimensional wavelength

$$
\lambda_{0}=2 \pi \frac{U_{c}}{f}(\alpha-1)^{1 / 2}
$$

with $f$ being the Coriolis parameter: $f=1.4 \times 10^{-4} \mathrm{~s}^{-1}$. This gives

$$
(\alpha-1)^{1 / 2}=\frac{2.8}{\pi U_{\mathrm{c}}} \text { where } U_{\mathrm{c}}=\left(g^{\prime} U_{\mathrm{h}}\right)^{1 / 3} .
$$

In the expression of $U_{\mathrm{c}}, g^{\prime}$ and $h$ are well known.

Observations (Valtat and others, 1960) show that we can expect temperature gradients from $5 \mathrm{~K}$ up to $10 \mathrm{~K}$ between the cold air layer and the warmer air on top. In this case, for a mean cold-air temperature of $250 \mathrm{~K}, g^{\prime}$ varies from 0.2 to $0.4 \mathrm{~m} \mathrm{~s}^{-2}$. The thickness of the cold air layer usually varies from 500 to $1000 \mathrm{~m}$. $U$, however, is not known. It is the mean speed of the cold air which flows down the slope due to gravity in a uniform and steady manner (Ball, 1956). For $U$, let us take a very low value of $1 \mathrm{~m} \mathrm{~s}^{-1}$ together with the lowest values for $g^{\prime}(0.2)$ and for $h(500 \mathrm{~m})$. In this case, $U_{\mathrm{c}}=4.64 \mathrm{~m} \mathrm{~s}^{-1}$.

Considering these assumptions, we obtain a maximum value of $\alpha$

$$
\begin{aligned}
& \alpha=1+(2.8 / 4.64 \pi)^{2}, \\
& \alpha=1+0.04 .
\end{aligned}
$$


$\alpha$ must satisfy the $\alpha>1$ condition, and nevertheless remains at a value around 1 .

This result excludes the exact maximum-amplitude solution (Equation (8)). Indeed, we respect the condition:

$$
|k|<\left(\alpha^{1 / 3}-1\right)^{3 / 2}
$$

but

$$
|k|=\frac{\bar{z}}{\bar{x}}=\frac{g^{\prime}}{U_{\mathrm{c}} f}\left|\frac{z}{x}\right|
$$
have

Since the relief drops about $2000 \mathrm{~m}$ over $200 \mathrm{~km}$, we

$$
\left|\frac{z}{x}\right|=10^{-2}
$$

Furthermore, since $\alpha$ must be about $1, U_{\mathrm{c}}$ is required to be of the same order of magnitude as $U_{\mathrm{g}}$. If we choose a high value of $U_{\mathrm{c}}\left(30 \mathrm{~m} \mathrm{~s}^{-1}\right)$ and a low value of $g^{\prime}(0.2)$, so that $|k|$ must be small, we find:

$$
\begin{aligned}
|k| & \propto 0.95 ; \text { this value leads to } \\
\alpha & =\left[(0.95)^{2 / 3}+1\right]^{3}=7.62 .
\end{aligned}
$$

We conclude that the only possible solution is the one corresponding to a disturbance occurring near geostrophic equilibrium and satisfying the system of Equations (9).

However, we must verify that $\alpha$ can be equal to 1 and that it stays near this value.

We have seen that $\alpha$ can be written as the product of two Froude numbers:

$$
\alpha=F g F u^{-1 / 3}
$$

where $F g=u_{\mathrm{g}} /\left(g^{\prime} h\right)^{1 / 2}$ is a Froude number induced by the geostrophic wind and $F u=u /\left(g^{\prime} h\right)^{1 / 2}$ is a Froude number induced by the uniform speed of the flow. Ball (1956) has shown that this Froude number depends only on the relationship $F u=k / C_{\mathrm{D}}$ where $k$ is the slope of the field and $C_{\mathrm{D}}$ is a viscosity coefficient, depending on the surface structure.

So, although $U$ and $h$ can vary along the slope (we generally admit that $g^{\prime}$ variation is low), the Froude number $F u$ of uniform flow remains constant.

We know that $k=10^{-2}$ but $C_{\mathrm{D}}$ is unknown for the study location. However, Ball (1956) obtained $C_{\mathrm{D}}$ values ranging from $10^{-2}$ down to $5 \times 10^{-3}$, so $F u$ therefore changes from 1 to 2 and the condition $\alpha=1$ therefore implies that:

$$
F g=F u^{1 / 3} .
$$

$F g$ values will range between $F g=1$ and $F g=1.26$. These values will easily be reached, since the selection of relatively large values for $g^{\prime}\left(0.4 \mathrm{~m} \mathrm{~s}^{-1}\right)$ and $h(1000 \mathrm{~m})$ gives $F g=1.26$ if $U_{\mathrm{g}}=25.2 \mathrm{~m} \mathrm{~s}^{-1}$, which is very reasonable considering the mean wind speed observed in Terre Adélie.

Finally, we note that the order of magnitude of values given by observations for the variables giving the Froude number (geostrophic wind, modified gravity, and layer thickness) lead to $F g \simeq 1$.

This Froude number represents flow occurring in an area showing marked regularity: uniform surface slope over a long distance; very homogeneous nature and temperature of the surface; atmospheric circulation induced by a slowly changing temperature gradient (continent to sea); stable cold air.

Unfortunately, we presently have insufficient data from lower-layer soundings to confirm this hypothesis.

It can be concluded that a gravity-inertia wave disturbing the geostrophic equilibrium may be formed. Its amplitude is weak but the triggering occurs at the break-in-slope location and the wavelength is of the same order of magnitude as the accumulation wavelength. The conditions for formation of this wave are strictly local in character.
If such an atmospheric wave originates the cyclic behavior of the snow accumulation along the slope in Terre Adélie, we must emphasize that it is a very special case which is unlikely to occur other than in Antarctica.

\section{CONCLUSION}

The dating of the snow layers or, in other words, the accumulation is an important parameter for the geochronological studies carried out on the ice cores. As important spatial and temporal variations in the accumulation exist in Antarctica, it is necessary to compare the results for different points to be able to normalize these measurements. Thus, by comparing the accumulation at two different sites, it is possible to measure this accumulation at the same time. On the other hand, by taking into account the scatter of the results due to variations with time, these temporal variations are in general much more important than the experimental error. Our work shows that, for an important zone, this normalization must be possible. In fact, more than $50 \%$ of the observed variations are not random.

The measurements carried out in the field with bamboo networks showed that the choice of a better reference area for the accumulation measurements should considerably reduce the noise due to sastrugi.

Finally, we suggest a plausible meteorological explanation for the spatial oscillations observed on a part of the measuring axis. For this zone, a parameterization of this phenomenon allows us to diminish the discrepancy between the measured and calculated accumulation in a significant manner.

\section{REFERENCES}

Alt, J. 1960. Quelques considérations générales sur la météorologie de l'Antarctique. Météorologie, Sér. IV, No. 57, p. 17-39.

Ball, F.K. 1956. The theory of strong katabatic winds. Australian Journal of Physics, Vol. 9, No. 3, p. 373-86.

Ball, F.K. 1960. Finite tidal waves propagated without change of shape. Journal of Fluid Mechanics, Vol. 9, p. 506.

Black, H.P., and Budd, W. 1964. Accumulation in the region of Wilkes, Wilkes Land, Antarctica. Journal of Glaciology, Vol. 5, No. 37, p. 3-15.

Cornet, A., and others. 1960. Accumulation de neige en Terre Adélie, by A. Cornet, C. Lorius, and G. Ricou. Météorologie, Sér. IV, No. 57, p. 175.

Crozaz, G. 1969. Fission products in Antarctic snow, an additional reference level in January 1965. Earth and Planetary Science Letters, Vol. 6, No. 1, p. 6-8.

Dallavalle, J.M. 1948. Micrometrics: the technology of fine particles. Second edition. Pitman Publishing Corporation, p. 411-15.

Garcia, R. 1960. Mesures du transport de neige par le vent à la Station Charcot. Météorologie, Sér. IV, No. 57, p. 205-12.

Gutman, L.N., and Khain, A.P. 1975. Mesometeorological processes in the free atmosphere governed by orography. English edition of Izvestiya, Academy of Sciences, USSR, Atmospheric and Oceanic Physics, Vol. 11, No. 2, p. 107-17.

Lambert, G., and others. 1977. Accumulation of snow and radioactive debris in Antarctica: a possible refined radiochronology beyond reference levels, by G. Lambert, B. Ardouin, J. Sanak, C. Lorius, and M. Pourchet. [Union Géodésique et Géophysique Internationale. Association Internationale des Sciences Hydrologiques. Commission des Neiges et Glaces.] Symposium. Isotopes et impuretés dans les neiges et glaces. Actes du colloque de Grenoble, août/septembre 1975, p. 146-58. (IAHS-AISH Publication No. 118.)

Lliboutry, L. 1974. Multivariate statistical analysis of glacier annual balances. Journal of Glaciology, Vol. 13, No. 69 p. $371-92$. 
Lorius, C., and Merlivat, L. 1977. Distribution of mean surface stable isotopes in East Antarctica: observed changes with depth in the coastal area. [Union Géodésique et Géophysique Internationale. Association Internationale des Sciences Hydrologiques. Commission des Neiges et Glaces.] Symposium. Isotopes et impuretés dans les neiges et glaces. Actes du colloque de Grenoble, août/septembre 1975 , p. 127-37. (IAHS-AISH Publication No. 118.)

Lorius, C., and others. 1970. Dating of firn layers in Antarctica: application to the determination of the rate of snow accumulation, by C. Lorius [and 8 others]. [Union Géodésique et Géophysique Internationale. Association Internationale d'Hydrologie Scientifique.] [International Council of Scientific Unions. Scientific Committee on Antarctic Research. International Association of Scientific Hydrology. Commission of Snow and Ice.] International Symposium on Antarctic Glaciological Exploration (ISAGE), Hanover, New Hampshire, U.S.A., 3-7 September 1968, p. 3-15. [(Publication No. 86 de 1'Association Internationale d'Hydrologie Scientifique.)]

Male, D.H. 1980. The seasonal snowcover. (In Colbeck, S.G., ed. Dynamics of snow and ice masses. New York, Academic Press, p. 305-95.)

Petit, J.R., and others. 1982. A detailed study of snow accumulation and stable isotope content in Dome C (Antarctica), by J.R. Petit, J. Jouzel, M. Pourchet, and L. Merlivat. Journal of Geophysical Research, Vol. 87, No. C6, p. 4301-08.
Picciotto, E., and Wilgain, S. 1963. Fission products in Antarctic snow, a reference level for measuring accumulation. Journal of Geophysical Research, Vol. 68, No. 21 , p. 5965-72.

Picciotto, E., and others. 1964. Rate of accumulation of snow at the South Pole as determined by radioactive measurements, by E. Picciotto, G. Crozaz, and W. de Breuck. Nature, Vol. 203, No. 4943, p. 393-94.

Pourchet, M., and others. 1983. Some meteorological applications of radioactive fallout measurements in Antarctic snows, by M. Pourchet, F. Pinglot, and C. Lorius. Journal of Geophysical Research, Vol. 88, No. C10, p. 6013-20.

Radok, U. 1968. Deposition and erosion of snow by the wind. CRREL Research Report 230.

Radok, U. 1977. Snow drift. Journal of Glaciology, Vol. 19 , No. 81 , p. 123-139.

Reynaud, L., and others. 1984. Spatio temporal distribution of the glacial mass balance in the Alpine, Scandinavian and Tien Shan areas, by L. Reynaud, M. Vallon, S. Martin, and A. Letreguilly. Geografiska Annaler, Vol. $66 \mathrm{~A}$, No. 3, p. 239-47.

Valtat, B. 1960. Note sur les modifications de structure thermique des basses couches pour divers régimes de vent au sol à Dumont-d'Urville. Météorologie, Sér. IV, No. 57 , p. $127-33$

Valtat, B., and others. 1960. Le "phénomène de Loewe" en Terre Adélie, by B. Valtat, J. Gilbert, and R. Magniez. Météorologie, Sér. IV, No. 57, p. 77-112. 